OAK RIDGE NATIONAL LABORATORY

LOCKHEED MARTINT/7

\title{
ORR Deer Hunt Monitoring Program
}

P. A. Scofield

N. A. Teasley, Jr.

RECEIVED

SEP 20

1999

OSTI

MANAGED AND OPERATED BY

LOCKHEED MARTM ENERGY RESEARCH CORPORATION FOR THE UNTED STATES

DEPARTMEHT OF ENERGY

ORNL-27 (3.90) 
This report has been reproduced from the best available copy.

Reports are available to the public from the following source. National Technical Information Service 5285 Port Royal Road Springfield, VA 22161

Telephone 703-605-6000 (1-800-553-6847)

TDD 703-487-4639

Fax 703-605-6900

E-mail orders@ntis.fedworld.gov

Web site http://www.ntis.gov/ordering.htm

Reports are available to U.S. Department of Energy (DOE) employees, DOE contractors, Energy Technology Data Exchange (ETDE) representatives, and International Nuclear Information System (INIS) representatives from the following source.

Office of Scientific and Technical Information

P.O. Box 62

Oak Ridge, TN 37831

Telephone 423-576-8401

Fax 423-576-5728

E-mail reports@adonis.osti.gov

Web site http://www.osti.gov/products/sources.html

Reports produced after January 1,1996 , are generally available via the DOE Information Bridge.

Web site http://www.doe.gov/bridge 


\section{DISCLAIMER}

This report was prepared as an account of work sponsored by an agency of the United States Government. Neither the United States Government nor any agency thereof, nor any of their employees, make any warranty, express or implied, or assumes any legal liability or responsibility for the accuracy, completeness, or usefuiness of any information, apparatus, product, or process disclosed, or represents that its use would not infringe privately owned rights. Reference herein to any specific commercial product, process, or service by trade name, trademark, manufacturer, or otherwise does not necessarily constitute or imply its endorsement, recommendation, or favoring by the United States Government or any agency thereof. The views and opinions of authors expressed herein do not necessarily state or reflect those of the United States Government or any agency thereof. 


\section{DISCLAIMER}

Portions of this document may be illegible in electronic image products. Images are produced from the best available original document. 
ORNL/TM-13719

\title{
ORR Deer Hunt Monitoring Program
}

\author{
P. A. Scofield and N. A. Teasley, Jr. \\ Office of Environmental Protection and Chemical and Analytical Sciences Division
}

Date Issued -- September 1999

Prepared by the Oak Ridge National Laboratory Oak Ridge, Tennessee 37831

managed by

Lockheed Martin Energy Research for the U.S. DEPARTMENT OF ENERGY under contract DE-AC05-96OR22464 



\section{CONTENTS}

ACKNOWLEDGMENTS $\ldots \ldots \ldots \ldots \ldots \ldots \ldots \ldots \ldots \ldots \ldots \ldots \ldots \ldots$ vii

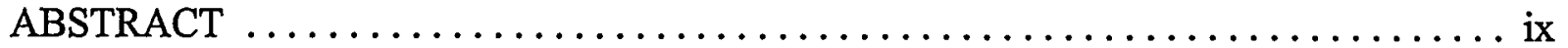

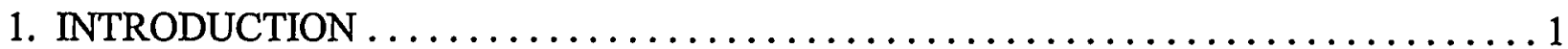

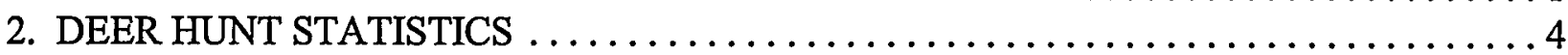

3. FIELD AND LABORATORY ANALYTICAL RESULTS $\ldots \ldots \ldots \ldots \ldots \ldots \ldots \ldots \ldots$

4. EFFECTIVE DOSE EQUTVALENT ESTIMATES $\ldots \ldots \ldots \ldots \ldots \ldots \ldots \ldots \ldots \ldots \ldots \ldots \ldots \ldots$

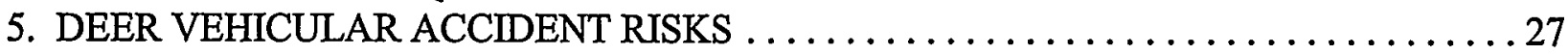

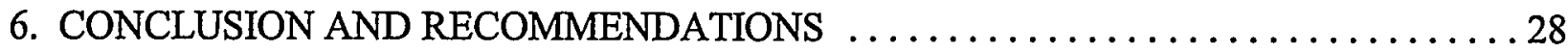

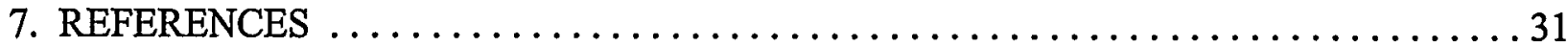

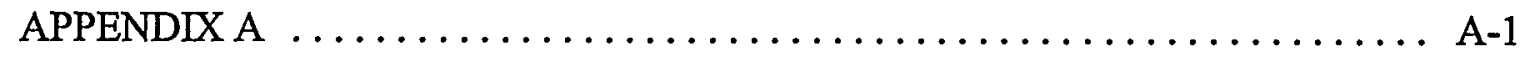

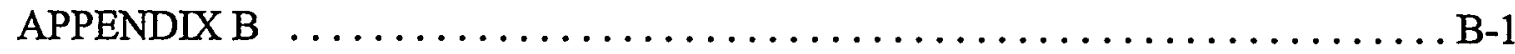

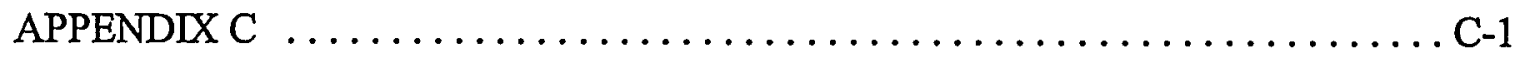

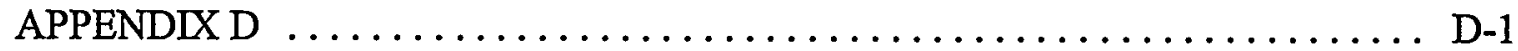




\section{TABLES}

Table 1. Number of Samples Analyzed in the Laboratory ................... 12

Table 2. Analytical Results of Tissue and Bone Samples from Deer Harvested Off-site . . . . . 22

\section{FIGURES}

Figure 1. 1997 ORR Deer Hunt Map . . . . . . . . . . . . . . . . . . . . . . . . 2

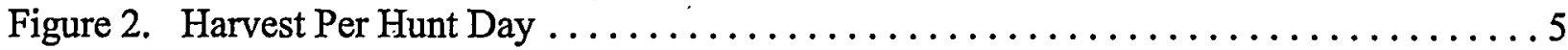

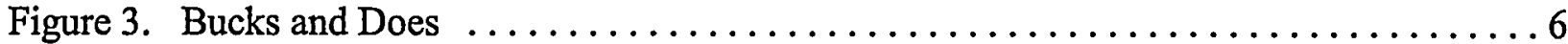

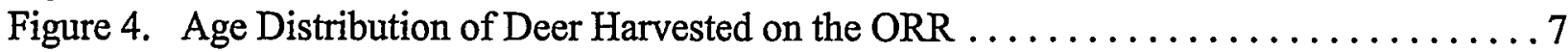

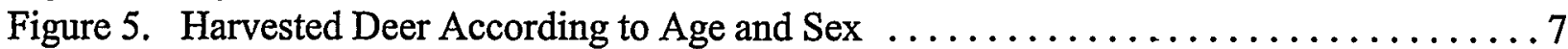

Figure 6. Annual Age Distribution of Harvested Deer $\ldots \ldots \ldots \ldots \ldots \ldots \ldots \ldots \ldots \ldots$

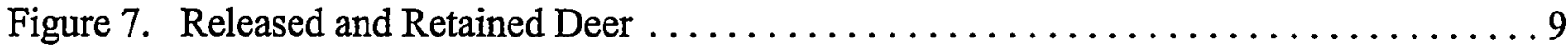

Figure 8. Cs-137 Mean Concentrations - Field Analyses $\ldots \ldots \ldots \ldots \ldots \ldots \ldots \ldots \ldots$

Figure 9. Average Gross Beta Activity (cpm) in Bone -- Field Data .............. 11

Figure 10. Comparison of Cs-137 Liver Field Concentration to Liver Laboratory Concentrations - At or Below Administrative Limits . . . . . . . . . 13

Figure 11. Comparison of Field Cs-137 Liver Concentrations to Laboratory Laboratory Muscle Concentrations -- At or Below Adminstrative Limits . . . . . . 14

Figure 12. Correlation of Gross Beta Field Data to Sr-90 Bone Concentrations -All Deer Data ..................................... 15

Figure 13. Comparison of Field Beta Count Rate Data to Sr-90 Laboratory Concentrations in Bone -- Retained Deer . ...................... 16

Figure 14. Comparison of Field Beta Count Rate Data to Laboratory Sr-90 Concentrations in Bone -- Released Deer . ...................... 16

Figure 15. Comparison of Sr-90 Concentrations in Bone and Tissue -- Retained and Released Deer ................................. 17

Figure 16. Comparison of Sr-90 Concentrations in Bone and Tissue of

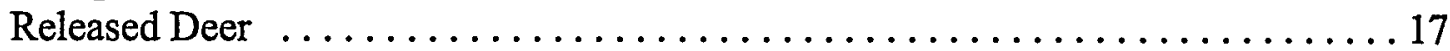

Figure 17. Comparison of Sr-90 Tissue and Bone Concentrations -- Retained

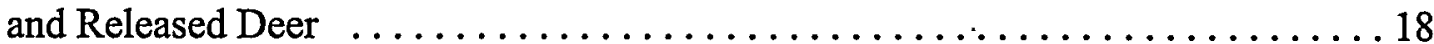

Figure 18. Comparison of Sr-90 Tissue and Bone Concentrations -- Released Deer . . . . . 19

Figure 19. Radioiodine Concentrations in Deer Thyroid Glands $\ldots \ldots \ldots \ldots \ldots . \ldots 20$

Figure 20. Co-60 Concentrations Measured in Deer Tissue .................... 21

Figure 21. Maximum EDEs due to Consumption of Venison from Deer Harvested

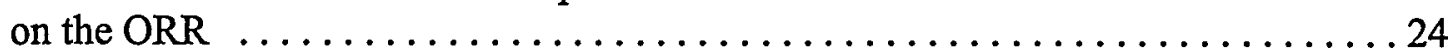

Figure 22. Estimated EDEs for Hunter/Households which Harvested Two or Three

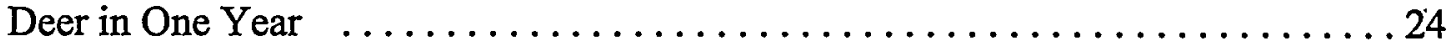

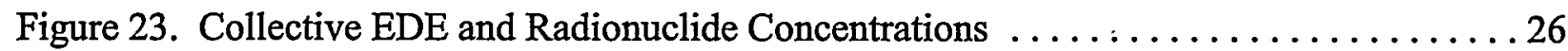

Figure 24. Annual Number of Deer Killed by Vehicles $\ldots \ldots \ldots \ldots \ldots \ldots \ldots \ldots \ldots \ldots \ldots$ 


\section{ACKNOWLEDGMENTS}

This program has been managed by the U.S. Department of Energy and the Tennessee Wildlife Resources Agency. Tennessee Wildlife Resources Agency staff, Oak Ridge National Laboratory staff and technicians, and members of the University of Tennessee Chapter of the Wildlife and Fisheries Society have put in many hours to support this program. The authors thank all of these individuals for their efforts to make this a successful and positive program for the Oak Ridge Reservation. 


\begin{abstract}
The primary purpose for the initiation of deer hunts on the Oak Ridge Reservation (ORR) was deer population control to reduce collisions with vehicles and maintain a healthy herd and habitat. As of 1997, thirteen annual deer hunts have been conducted on the ORR. The deer hunt monitoring program (DHMP) has two components -- a field screening monitoring program and a confirmatory laboratory analysis program of both retained and randomly selected released deer samples. Based on the field monitoring and laboratory analyses data the following observations were made:
\end{abstract}

- In all cases, field ${ }^{137} \mathrm{Cs}$ analyses (when compared to laboratory ${ }^{137} \mathrm{Cs}$ analyses) were capable of determining if ${ }^{137} \mathrm{Cs}$ concentrations in tissue were less than or exceeded the administrative limit of $5 \mathrm{pCi} / \mathrm{g}$.

- There is very good agreement between the field (cpm) screening of bone to laboratory measured ${ }^{90} \mathrm{Sr}$ concentrations in bone. A linear expression fits the data, resulting in an equation that can be used to provide an estimate of the ${ }^{90} \mathrm{Sr}$ concentration in bone from field gross beta measurements.

- There is not a good correlation between the ${ }^{90} \mathrm{Sr}$ concentrations in bone to ${ }^{90} \mathrm{Sr}$ concentrations in tissue. This discrepancy may be due to partitioning of the strontium throughout the body and is related to the time of intake and harvesting as well as the biological half-life of the radionuclide. However, regardless of the ${ }^{11} \mathrm{Sr}$ concentrations measured in bone, the maximum ${ }^{90} \mathrm{Sr}$ muscle concentration has not exceeded about $0.4 \mathrm{pCi} / \mathrm{g}$.

- Other radionuclides have been detected in deer harvested from the ORR -- most notably ${ }^{129} \mathrm{I}$ and ${ }^{131} \mathrm{I}$ in the thyroid glands and ${ }^{60} \mathrm{Co}$ in tissue. Iodine-129 has been the most frequently detected radioiodine. Cobalt- 60 has been infrequently detected.

- There was no significant difference (at the $95 \%$ Confidence Interval) between Cesium-137 concentrations detected in tissue samples from deer collected at "background" locations and ${ }^{137} \mathrm{Cs}$ concentrations measured in deer released from the ORR.

- In a survey conducted in 1997 , approximately $76 \%$ of the hunters said that they kept $80 \%$ or more of the venison, which was consumed by the immediate household. Thirty percent of the hunters surveyed considered themselves to be the primary consumers of the venison. 
- The maximum individual committed effective dose equivalent (EDE) from consumption of venison from a deer harvested on the ORR was estimated to be about 5 mrem. This EDE assumes that ${ }^{90} \mathrm{Sr}$ in tissue was at the maximum concentration of $0.4 \mathrm{pCi} / \mathrm{g}$. Estimated EDEs to selected hunters consuming venison from two or three deer harvested from the ORR ranged from about 0.3 mrem to $1.6 \mathrm{mrem}$. In two cases where four deer were harvested in one year by members of the same household, the estimated EDE for an individual who consumed all of the venison from the four deer was estimated to be about $6 \mathrm{mrem}$. In the one case where nine deer were harvested from the ORR by members of the same household (over a number of years), the estimated EDE to an individual that consumed all of the venison is $10 \mathrm{mrem}$. Estimated collective EDEs per annual harvest range from about 0.03 person-rem to 3 person-rem.

- In 1985, when the deer hunt was initiated; the risk of hitting and killing a deer in a deer vehicle collision was about $1.5 \times 10^{-5}$. In 1996, the risk of hitting and killing a deer decreased to about $4 \times 10^{-6}$. There are cases in which deer have been hit but not immediately killed (moved into undercover). It is unknown how many cases there have been, but if it is assumed that 30 percent more deer have been killed than have been enumerated as road kills, the risk of hitting a deer (and potentially causing vehicular damage) increases to about $2 \times 10^{-5}$ and $5 \times 10^{-6}$, respectively. 


\section{INTRODUCTION}

The primary purpose for the initiation of deer hunts on the Oak Ridge Reservation was deer population control. Such control is necessary to (1) reduce the incidence of deer/vehicle collisions on roads traversing the ORR; (2) maintain a healthy deer herd; and (3) prevent deer from damaging habitat for other animals and plants. As of 1997, thirteen annual deer hunts have been conducted on the ORR. The deer hunts are managed by the United States Department of Energy (DOE) and the Tennessee Wildlife Resources Agency (TWRA). Oak Ridge National Laboratory (ORNL) staff, TWRA staff, and student members of the University of Tennessee Chapter of the Wildlife and Fisheries Society are involved in the deer weighing, survey, sample collection and analysis activities at the deer checking station which is located off Bethel Valley Road approximately five miles east of ORNL.

Typically, the annual deer hunts are conducted over three weekends, starting with the third weekend of October and extending into December. Both gun and archery hunts are conducted on the ORR. Figure 1 (1997 Deer Hunt Map) provides an example of the delineated areas of the ORR in which gun and archery hunts are permitted. From 1985 to 1997, a total of 6,787 deer has been harvested on the ORR. Of these deer, 158 (2.3\%) have been retained due to radiological contamination.

The deer hunt monitoring program (DHMP) has two components -- a field screening/monitoring program and a confirmatory laboratory analysis program of both retained and randomly selected released deer samples. Each hunter is required to field dress the deer and take it to the deer checking station. At the deer checking station each successful hunters' deer is weighed and aged along with analyzing a liver (or muscle when no liver is brought in by hunter) and a leg bone sample to check for radiological contamination. The bone sample is measured for gross beta activity (assumed to be ${ }^{90} \mathrm{Sr}$ ) using a plastic phosphor, beta scintillation detector. The liver (or muscle) sample is analyzed using a five minute count time by gamma-ray spectrometry (6" $\mathrm{NaI}(\mathrm{Tl})$ detector, multichannel analyzer). If the measurements exceed deer hunt radiation monitoring guidelines, $5 \mathrm{pCi} / \mathrm{g}$ in tissue for ${ }^{137} \mathrm{Cs}$ and a beta count rate in bone one and half times (1.5) background (about $20 \mathrm{pCi} / \mathrm{g}$ as ${ }^{90} \mathrm{Sr}$ ), the deer is retained (CASD-AM-RML-RA01, 1995). The guidelines were established to keep the dose as low as reasonably achievable (ALARA) along with concerns for releasing a hunter's deer in a reasonable time period. The beta count rate criteria is near the detection limit for the field measurements. Cesium-137 is the radionuclide commonly evaluated in the soft tissue sample; however, if other radionuclides are detected, the deer is retained for further analysis in the laboratory. As part of the laboratory analysis component of the DHMP program, for each retained deer, samples are taken and quantitatively analyzed in the laboratory, if funding is available. In addition, random deer tissue and bone samples which had been collected from deer that were released are also quantitatively analyzed in the laboratory, if funding for these laboratory analyses is available. 


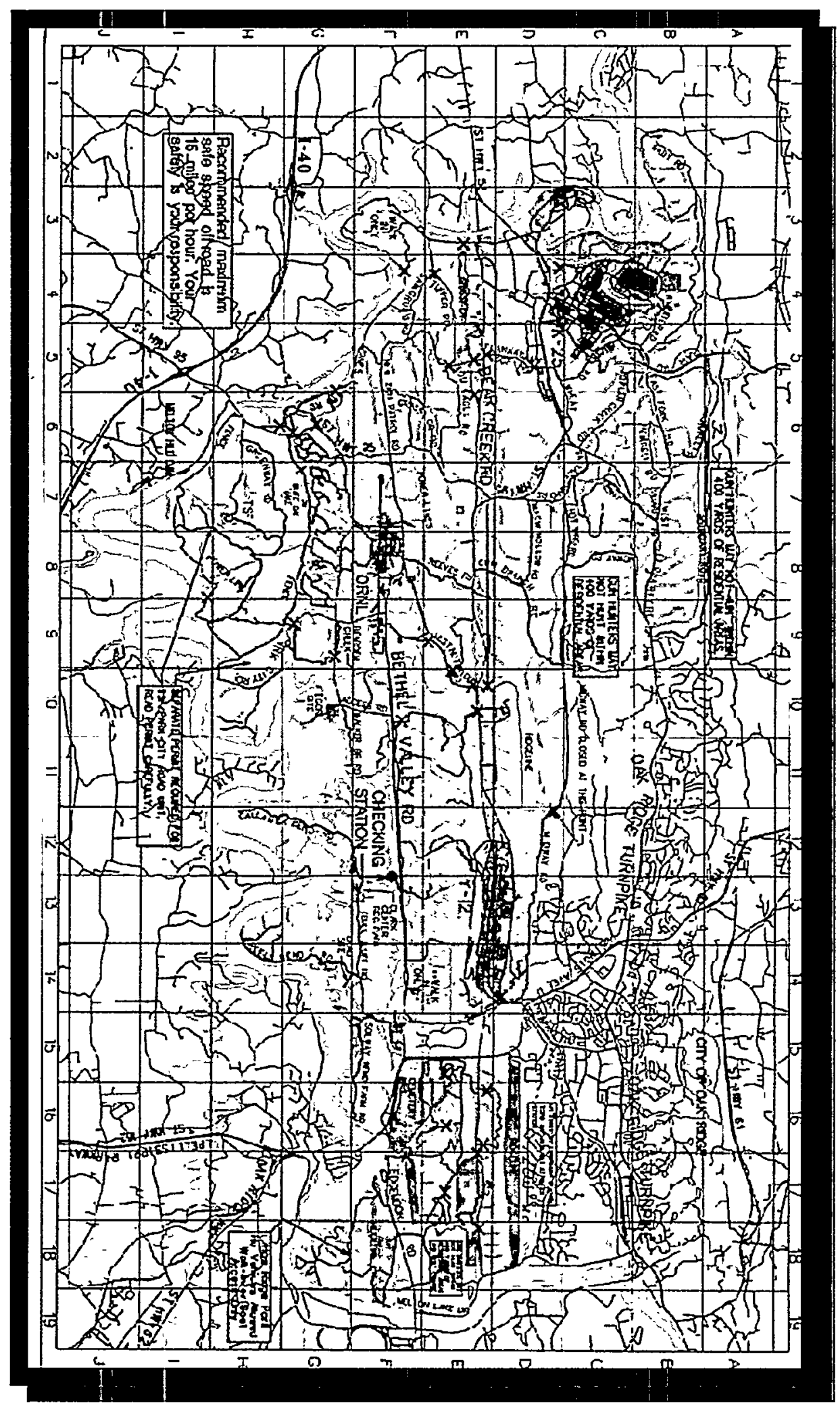

Figure 1

1997 ORR Deer Hunt Map 
Objectives of the deer hunt monitoring program (DHMP) are:

- To ensure that no deer harvested during the hunt are released to the public if the ${ }^{137} \mathrm{Cs}$ or beta activity in bone are above the administrative limits or if they are contaminated with other radionuclides.

- To verify that the field monitoring program reliably determines whether a deer may be released to the public.

- To track the number, age, sex, and weight of deer, as well as the percentage of contaminated deer on the ORR.

- To provide data which are used to estimate individual and collective effective dose equivalents for persons consuming venison harvested from the ORR.

This report is organized to summarize the DHMP data, to evaluate potential individual and collective EDEs to hunters harvesting deer on the ORR, and to determine if the deer hunts have reduced the deer population on the ORR. Section 2 summarizes deer hunt statistics on number, age, sex, and weight of deer harvested, number retained, and location of deer when harvested. Section 3 summarizes the field radionuclide data and then compares the field to laboratory data to evaluate if the field monitoring program is adequate for determining whether a deer should be retained or released to the public. Also in Section 3, background radionuclide concentrations found in off-site deer are reported. Section 4 contains estimates of individual and collective effective dose equivalents associated with the consumption of venison harvested from the reservation. The effect of the deer hunts on the deer population are presented in Section 5. Conclusions and recommendations for follow-up activities are provided in Section 6. 


\section{SECTION 2. DEER HUNT STATISTICS}

Deer hunt monitoring data used by this report has been gathered from thirteen annual hunts (1985 to 1997). The total number of deer harvested on ORR during this time frame is 6,787 . Of these deer, $158(2.3 \%)$ have been retained. The average number of deer checked at the checking station during the hunts has been 75 per hunt day, with a low of 12 on October 23, 1988, and a high of 189 on November 12, 1994. The numbers of deer harvested per hunt date are shown in Figure 2. A total of 2,935 does and 3,852 bucks have been collected. The number of bucks and does harvested per grid area of the hunting map are shown in Figure 3 (overlay on the 1997 hunt map). The majority of deer have been harrvested north and west of ORNL.

Figure 4 presents the age distribution of deer harvested from 1985 to 1997 . The average age of the deer harvested during the thirteen year period is 1.9 years, with ages ranging from 0.5 to 12.0 years. Ninety-five percent $(95 \%)$ of all deer harvested on the ORR ranged between the ages of 0.5 and 3.5 years. The oldest deer harvested, estimated to be 12 years old, was taken in 1989. Figure 5 presents the age distribution of deer harvested according to both age and sex. A greater number of bucks (particularly 1.5 year olds) were harvested than were does. Figure 6 is a schematic of the percent of harvested deer per year and according to age. The harvesting of 1.5 year old deer has increased from about $22 \%$ in 1985 to $48 \%$ of the harvest in 1997 . The harvesting of 3.5 and 4.5 year old deer has decreased from about $15 \%$ and $6 \%$ in 1985 to less than $5 \%$ and $1 \%$ of the harvest in 1997 , respectively. The harvesting of 0.5 year old and 2.5 year old deer has remained fairly constant over the thirteen years of the deer hunts of the ORR. The average weight of a deer harvested (field dressed) during the period is 85.3 pounds (lbs); the deer field dressed weights have ranged from $8 \mathrm{lbs}$ to $210 \mathrm{lbs}$.

Enumerated in the map in Figure 7 are the number of released and retained deer per one square mile grid. There are about three areas of the ORR, west of ORNL, in which the percentage of retained deer is greater than or equal to $5 \%$. There is one area $(06 \mathrm{G})$ from which about $22 \%$ of the deer harvested over a thirteen year period has been retained. Grid $06 \mathrm{G}$ is located at the confluence of the Clinch river and White Oak Creek and just west of solid waste burial sites located to the south of ORNL. 


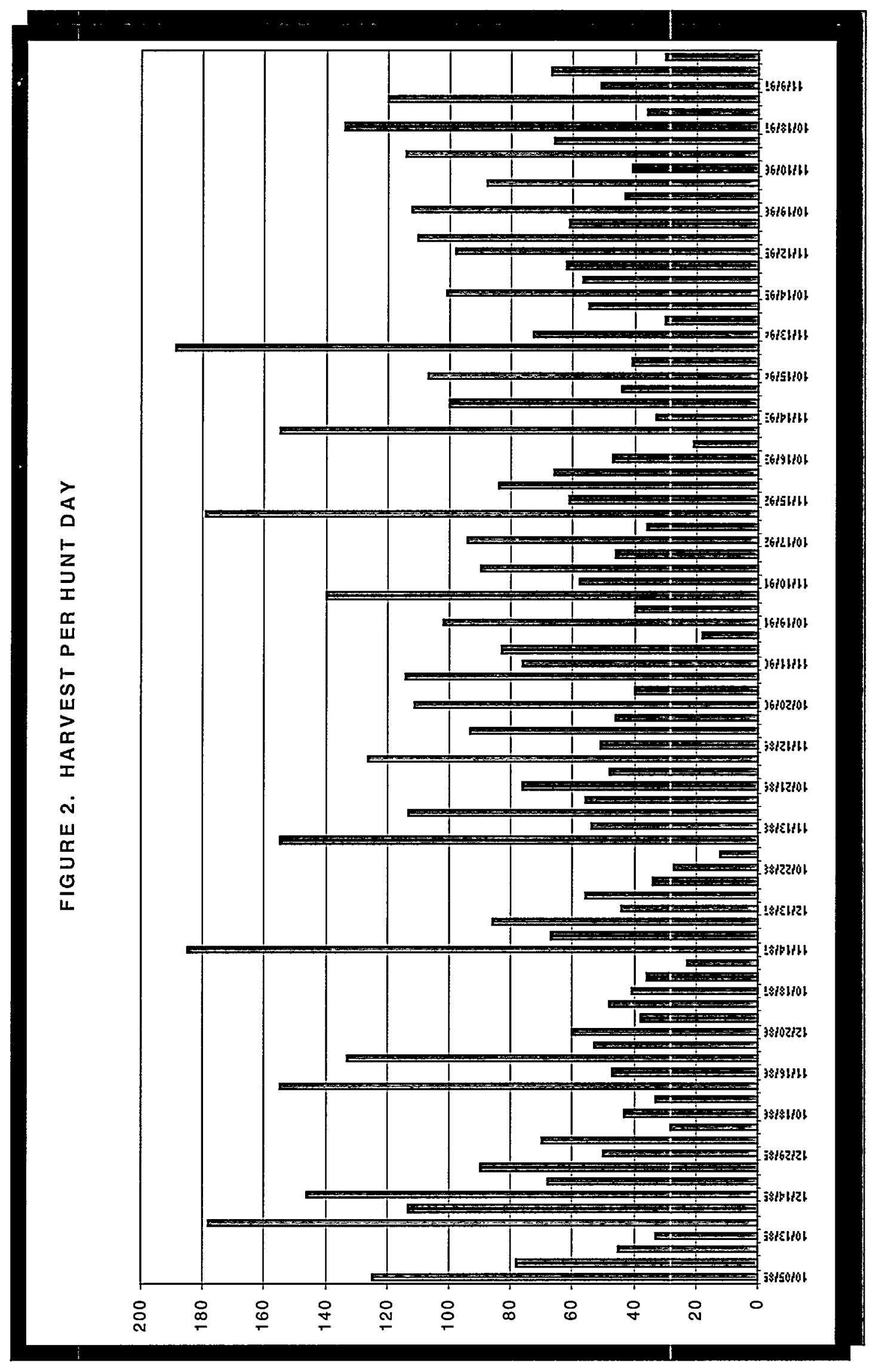




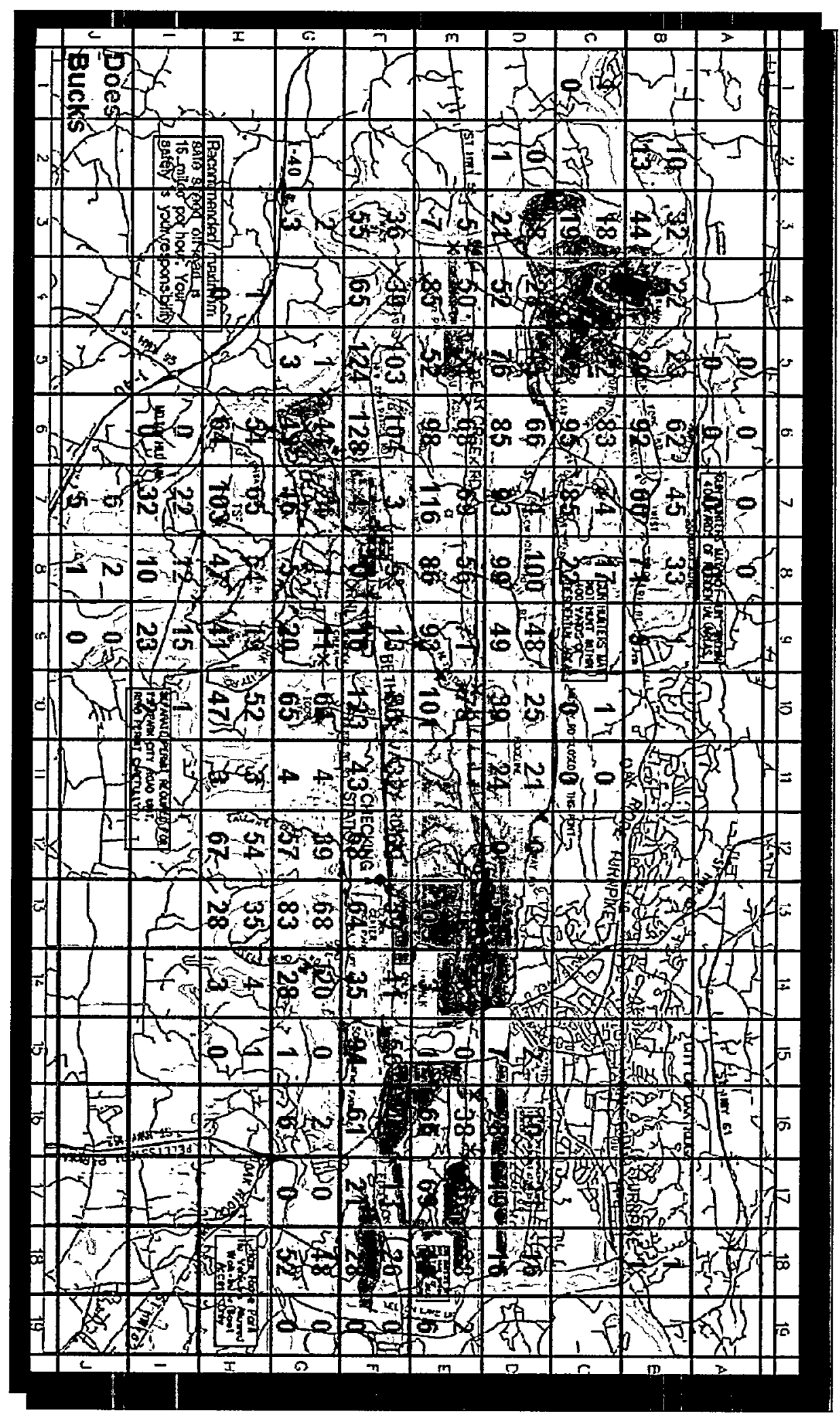

Figure 3

Bucks and Does 


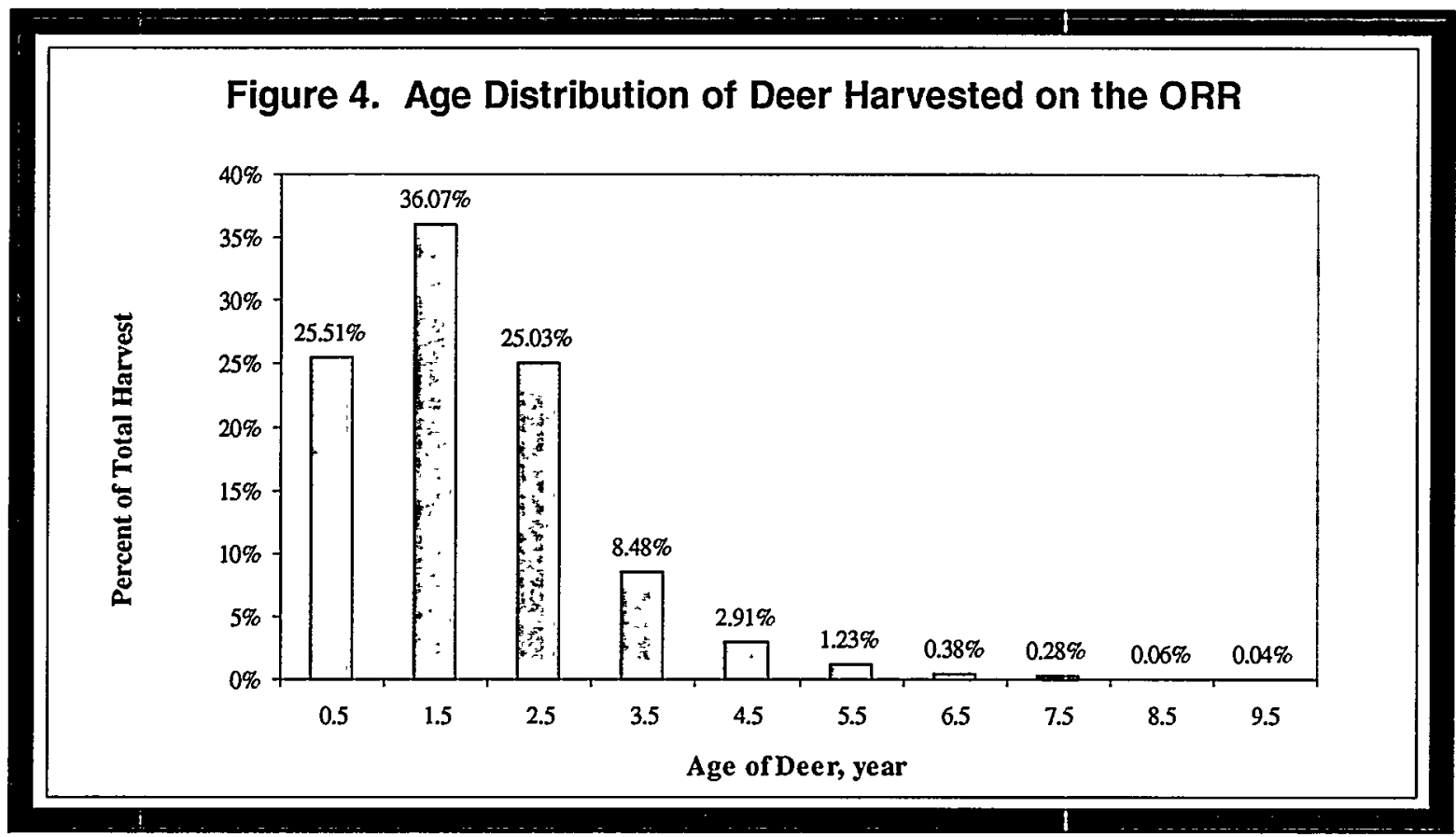

Figure 5. Harvested Deer According to Age and Sex

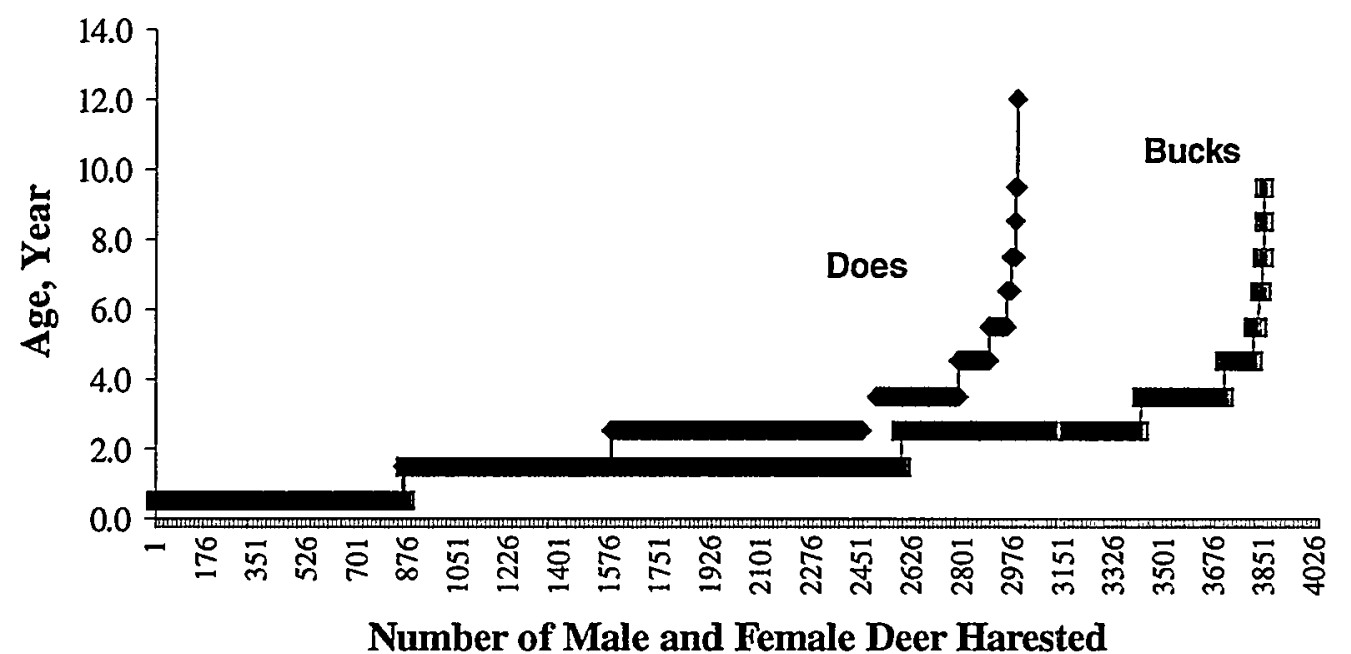

Number of Male and Female Deer Harested 


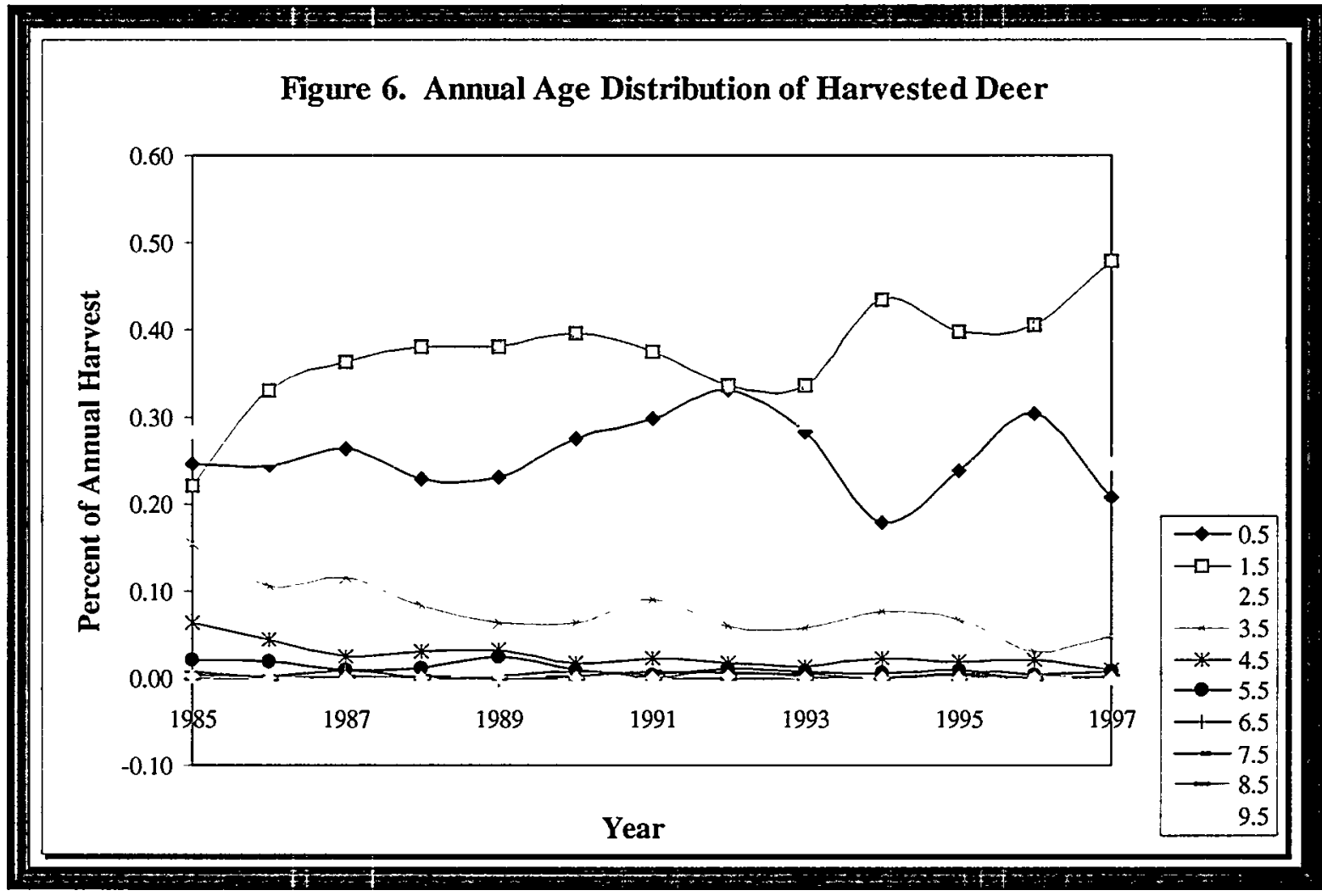




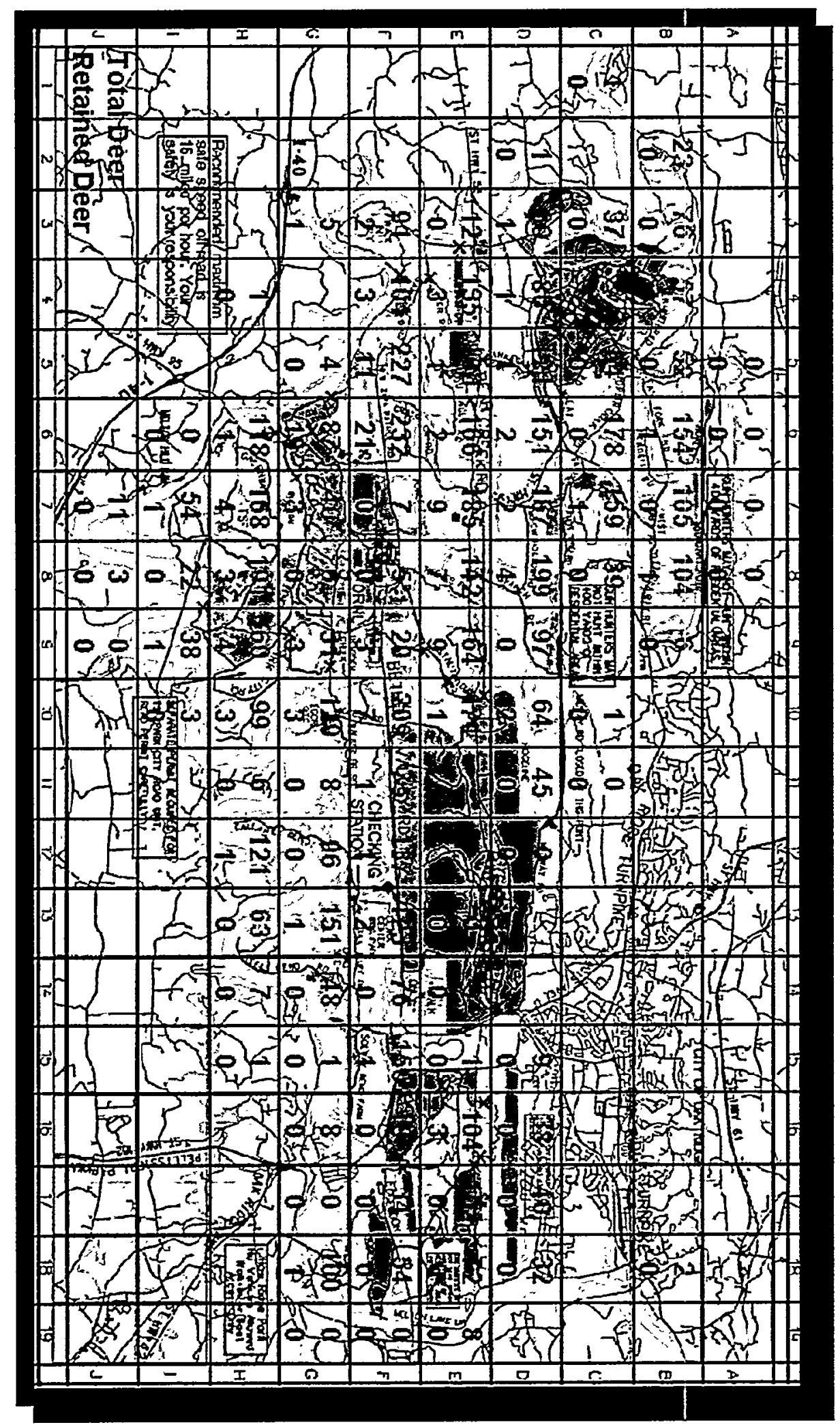

Figure 7

Released and Retained Deer 


\section{SECTION 3. FIELD AND LABORATORY ANALYTICAL RESULTS}

\subsection{Field Analytical Results}

Since the hunts began in 1985, every deer harvested on the ORR has had a liver or muscle sample analyzed for gamma activity (principally ${ }^{137} \mathrm{Cs}$ ) and a bone sample analyzed for gross beta activity. Figure 8 shows the $1986-1997$ mean field ${ }^{137} \mathrm{Cs}$ concentrations for the released and retained deer. Field ${ }^{137} \mathrm{Cs}$ concentrations detected in both retained and released deer has typically been very low, except during 1994. Two deer confiscated in 1994 had ${ }^{137} \mathrm{Cs}$ concentrations of $17 \mathrm{pCi} / \mathrm{g}$ and $740 \mathrm{pCi} / \mathrm{g}$, which resulted in a 1994 mean ${ }^{137} \mathrm{Cs}$ concentration of $94.9 \mathrm{pCi} / \mathrm{g}$ for retained deer. These deer were harvested in very different grid area locations $(06 \mathrm{D}$ and $10 \mathrm{H}$, respectively).

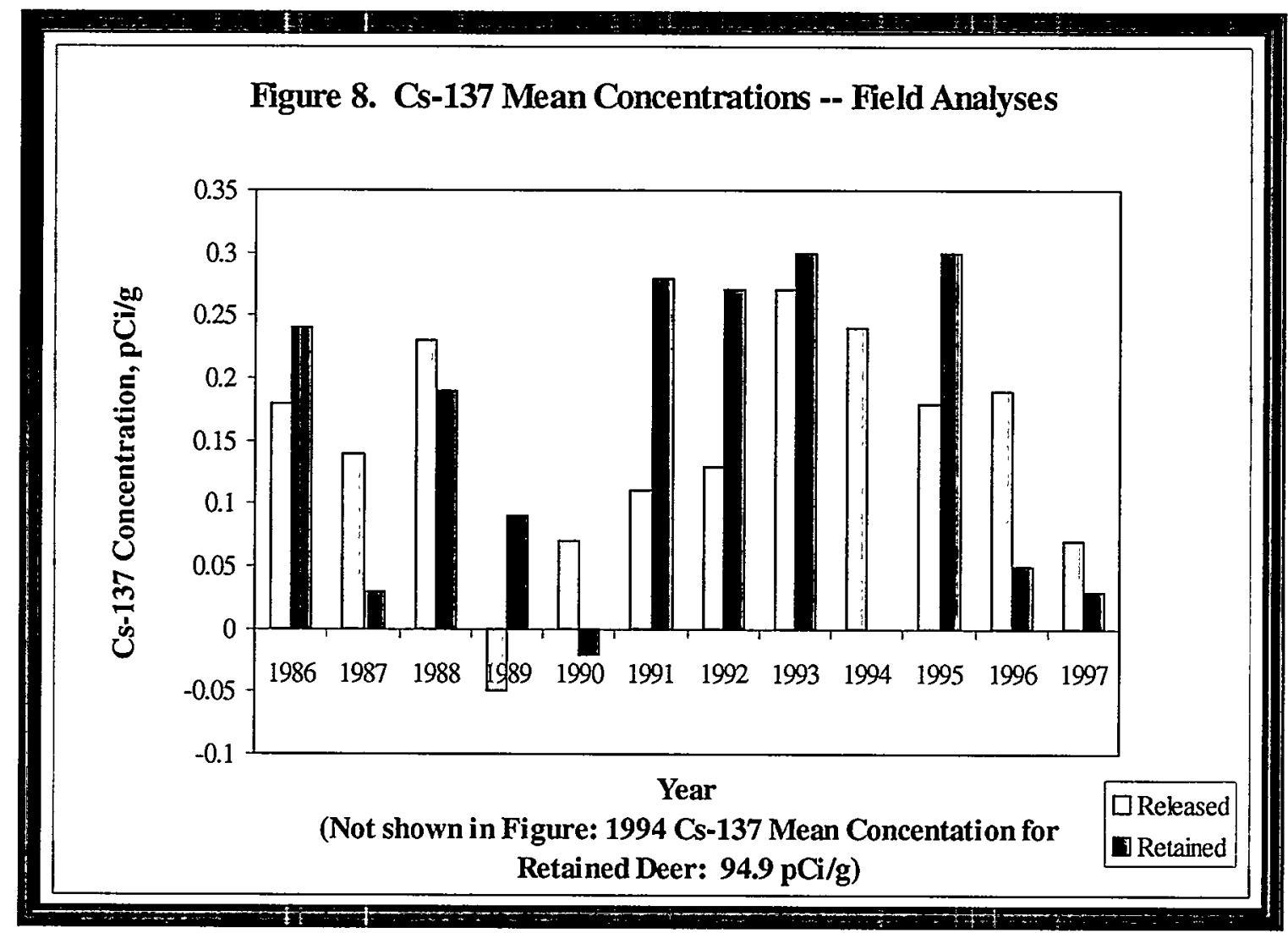


Figure 9 shows average annual field gross beta count rate data for both released and retained deer. The radioisotope contributing to the gross beta count rate is assumed to be ${ }^{90} \mathrm{Sr}$. This assumption has been confirmed by laboratory analyses; the gross beta count rate in bone has been very low in the released deer as compared to the retained deer. Most deer were retained because of elevated gross beta activity detected in bone samples.

Figure 9. Average Gross Beta Activity (cpm) in Bone -- Field Data

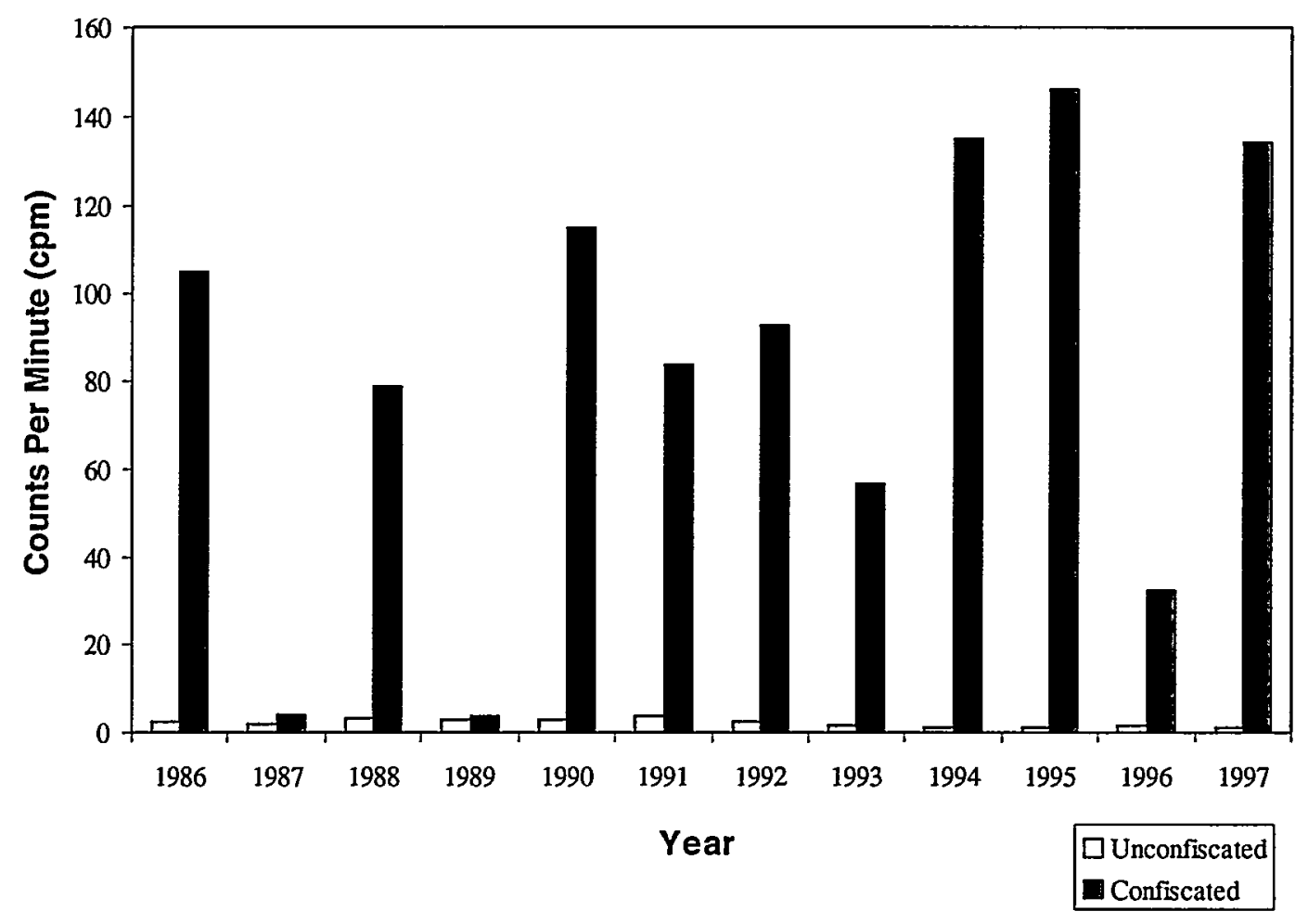




\subsection{Laboratory Analytical Data}

Along with the liver (if available), bone, thyroid, and muscle samples from retained deer, liver (or muscle), and bone samples were "randomly" selected from released deer (each $5^{\text {th }}, 10^{\text {th }}$, or $15^{\text {th }}$, dependent on the desired QA/QC requirements for the year's hunt ) and analyzed in the laboratory. The percent of deer sampled has ranged from a high of about $9 \%$ in 1994 to about $0.5 \%$ in 1985 . Since 1990 tissue samples have been consistently collected for analysis though not always analyzed. A summary of the number of samples collected per year and tissue type is shown in Table 1. The number of analytical results per tissue type ranges from about $1 \%$ to $3 \%$ of the total deer harvested. The deer hunt radiation monitoring guidelines (CASD-AM-RML-RA01) state that a random number of samples (approximately 10\%) from all deer plus the retained deer sampled are to be taken to the laboratory for verification analysis of ${ }^{137} \mathrm{Cs}$ in tissue and ${ }^{90} \mathrm{Sr}$ in bone. Recent statistical evaluations indicate that from all deer harvested annually, at least $5 \%$ $\mathrm{QA} / \mathrm{QC}$ random samples should be collected and analyzed.

Table 1. Number of Samples Analyzed in Laboratory

\begin{tabular}{|c|c|c|c|c|c|c|}
\hline Year & $\begin{array}{l}\text { Total Deer } \\
\text { Harvested }\end{array}$ & $\begin{array}{l}\text { Percent of Deer } \\
\text { Sampled }\end{array}$ & Liver Samples & $\begin{array}{l}\text { Muscle } \\
\text { Samples }\end{array}$ & $\begin{array}{l}\text { Bone } \\
\text { Samples }\end{array}$ & $\begin{array}{l}\text { Thyroid } \\
\text { Samples }\end{array}$ \\
\hline 1985 & 926 & $0.5 \%$ & 5 & 5 & 0 & 5 \\
\hline 1986 *(no data) & 660 & na & na & na & na & na \\
\hline $1987 *$ (unsure of data) & 530 & $\sim 5 \%$ & 0 & 0 & 27 & -28 \\
\hline $1988 *$ (no lab data) & 507 & na & na & na & na & na \\
\hline 1989*(no lab data) & 440 & na & na & na & na & na \\
\hline 1990 & 442 & $7.5 \%$ & 3 & 3 & 33 & 0 \\
\hline 1991 & 476 & $3 \%$ & 12 & 6 & 16 & 0 \\
\hline 1992 & 520 & $6.7 \%$ & 6 & 6 & 20 & 11 \\
\hline 1993 & 400 & $5.3 \%$ & 20 & 6 & 19 & 6 \\
\hline 1994 & 495 & $9.5 \%$ & 35 & 25 & 44 & 21 \\
\hline 1995 & 489 & $7.2 \%$ & 27 & 11 & 33 & 10 \\
\hline 1996 & 464 & $5 \%$ & 23 & 4 & 25 & 3 \\
\hline 1997 & 438 & $2 \%$ & 8 & 0 & 0 & 9 \\
\hline Total: & 6787 & 254 & 139 & 66 & 217 & 93 \\
\hline Percent of total: & & $3.7 \%$ & $2.0 \%$ & $1.0 \%$ & $3.2 \%$ & $1.4 \%$ \\
\hline
\end{tabular}




\subsection{Comparison of Field and Laboratory Results}

The field and laboratory analytical results from 1990 to 1997 are used in the following data comparisons.

\subsubsection{Comparison of Cesium-137 Field to Laboratory Analytical Results}

There have been only two cases in which the ${ }^{137} \mathrm{Cs}$ concentrations were greater than the administrative limit of $5 \mathrm{pCi} / \mathrm{g}$. For these two deer, the field ${ }^{137} \mathrm{Cs}$ concentrations in tissue were 17 $\mathrm{pCi} / \mathrm{g}$ and $740 \mathrm{pCi} / \mathrm{g}$, respectively. Both deer were retained. In all cases, field ${ }^{137} \mathrm{Cs}$ analyses were capable of determining if ${ }^{137} \mathrm{Cs}$ concentrations in tissue were less than or exceeded the administrative limit. Figures 10 and 11 present the ${ }^{137} \mathrm{Cs}$ concentrations at or below the administrative limit measured by both laboratory analyses (liver and muscle, respectively) to field (liver) measurements. It is evident that there is not a linear relationship between the field and laboratory analyses. In general, higher ${ }^{137} \mathrm{Cs}$ concentrations are measured in the muscle as compared to the liver field measurements. As one would expect, the liver ${ }^{137} \mathrm{Cs}$ concentrations measured in the field and in the laboratory are more consistent.

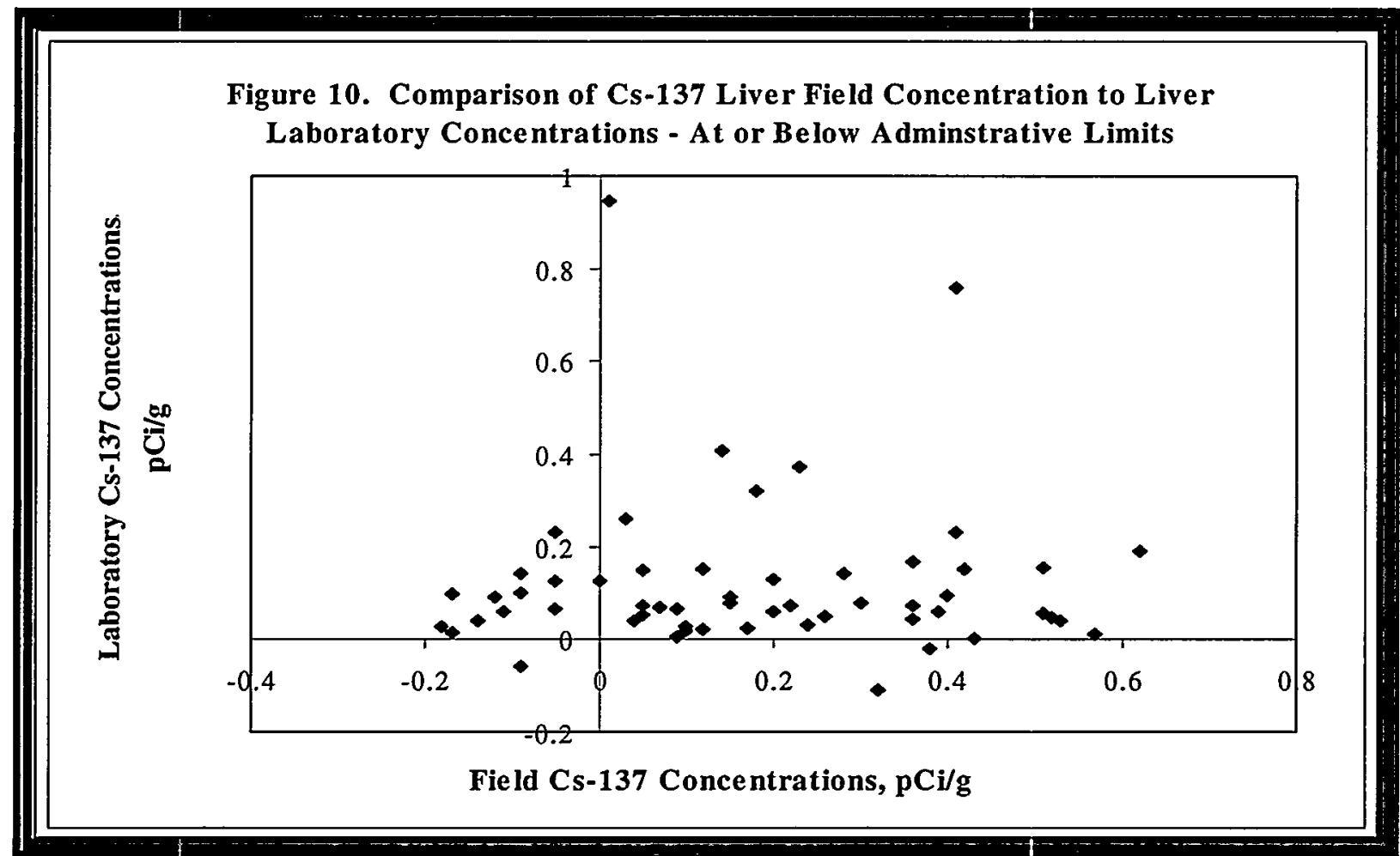




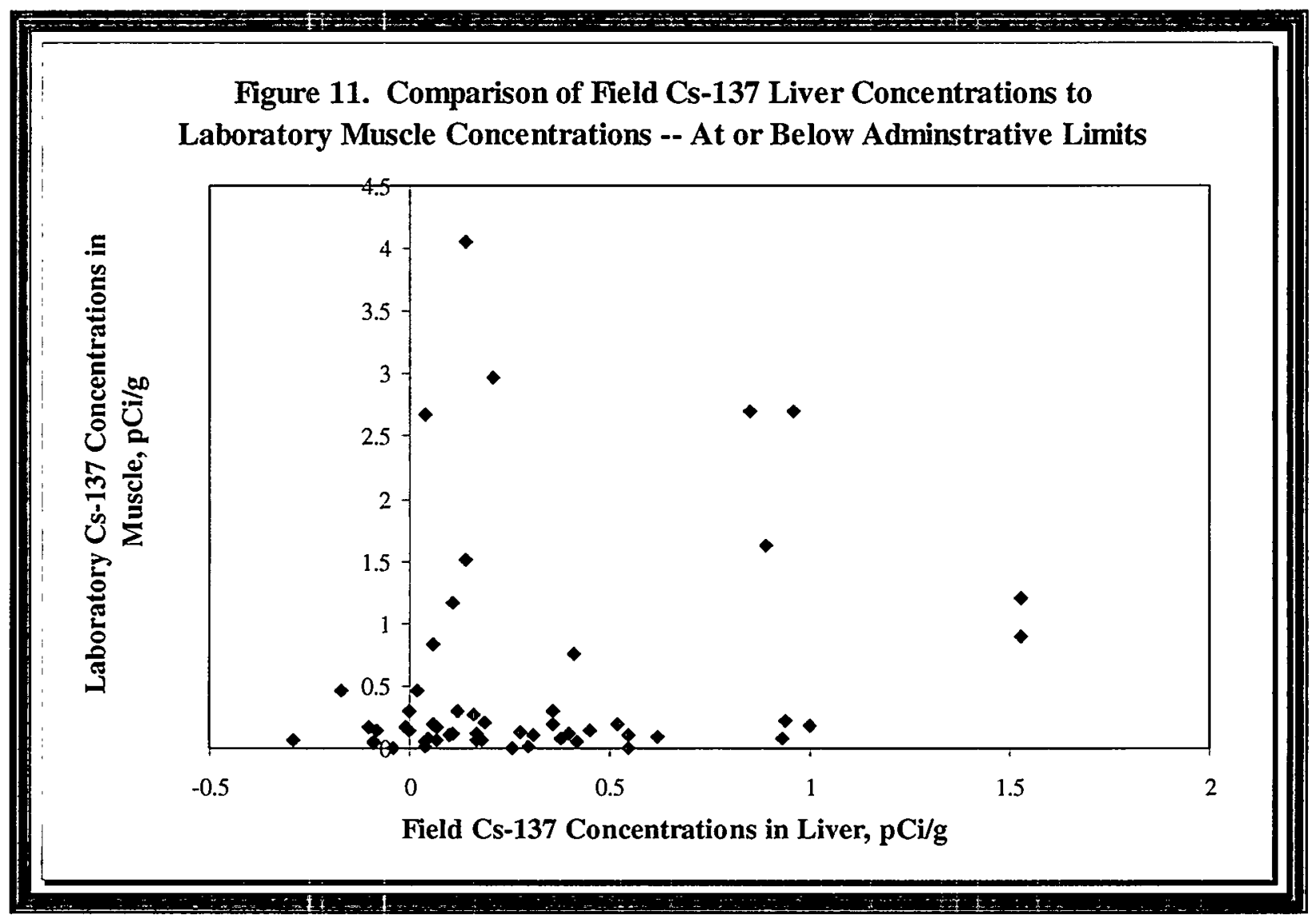

\subsubsection{Comparison of Field Gross Beta Count Rate to Strontium-90 Analytical Data}

Figure 12 presents a correlation of field gross beta count rate data to measured ${ }^{90} \mathrm{Sr}$ concentrations in bone in the same deer samples. Prior to November 14, 1992, a one minute counting time for beta detection in bone was used in the field; however, in later years 2 minute counts have been used in the field. There is a good linear relationship $(r=0.88)$ between the field gross beta count rate data and the measured ${ }^{90} \mathrm{Sr}$ concentrations in bone. As expressed by the linear regression equation: $y=1.416 x-0.3429$, a field count rate of $10 \mathrm{cpm}$ results in a ${ }^{90} \mathrm{Sr}$ bone concentration of about $14 \mathrm{pCi} / \mathrm{g}(0.52 \mathrm{~Bq} / \mathrm{g})$.

Figure 13 and Figure 14 provide comparisons between the field gross beta count rate measurements to the radioanalytical ${ }^{90} \mathrm{Sr}$ concentrations in bone in retained and released deer, respectively. There is less variation of gross beta count rate values to the measured ${ }^{90} \mathrm{Sr}$ concentrations in bone in retained deer as compared to released deer (Figure 13 and 14, respectively). As shown in Figure 13, the field gross beta count rate measurements have been effective in preventing release of deer containing more than $20 \mathrm{pCi} / \mathrm{g}$ of ${ }^{90} \mathrm{Sr}$ in bone. However, there were three cases in which deer were released above the administrative limit, as verified by laboratory analysis. 
Figure 12. Correlation of Gross Beta Field Data to Sr-90 Bone Concentrations --All Deer Data

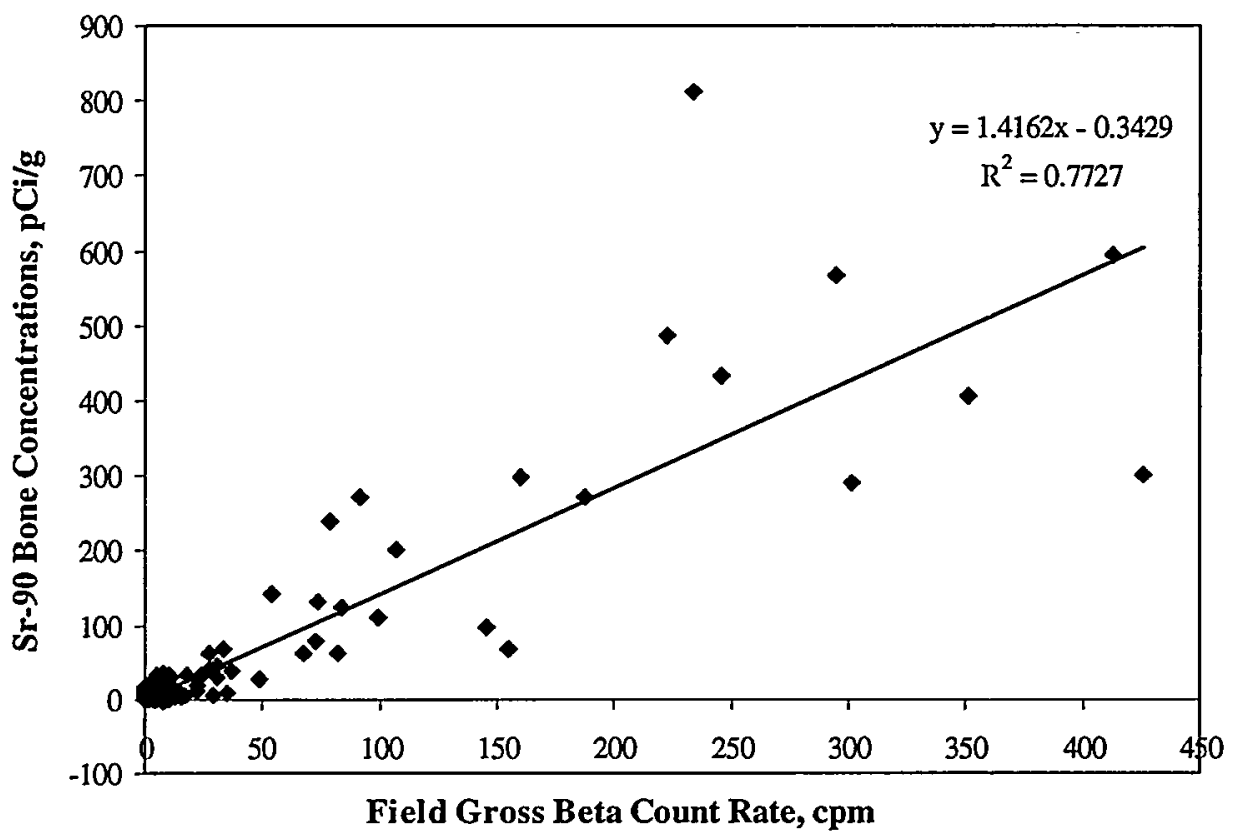



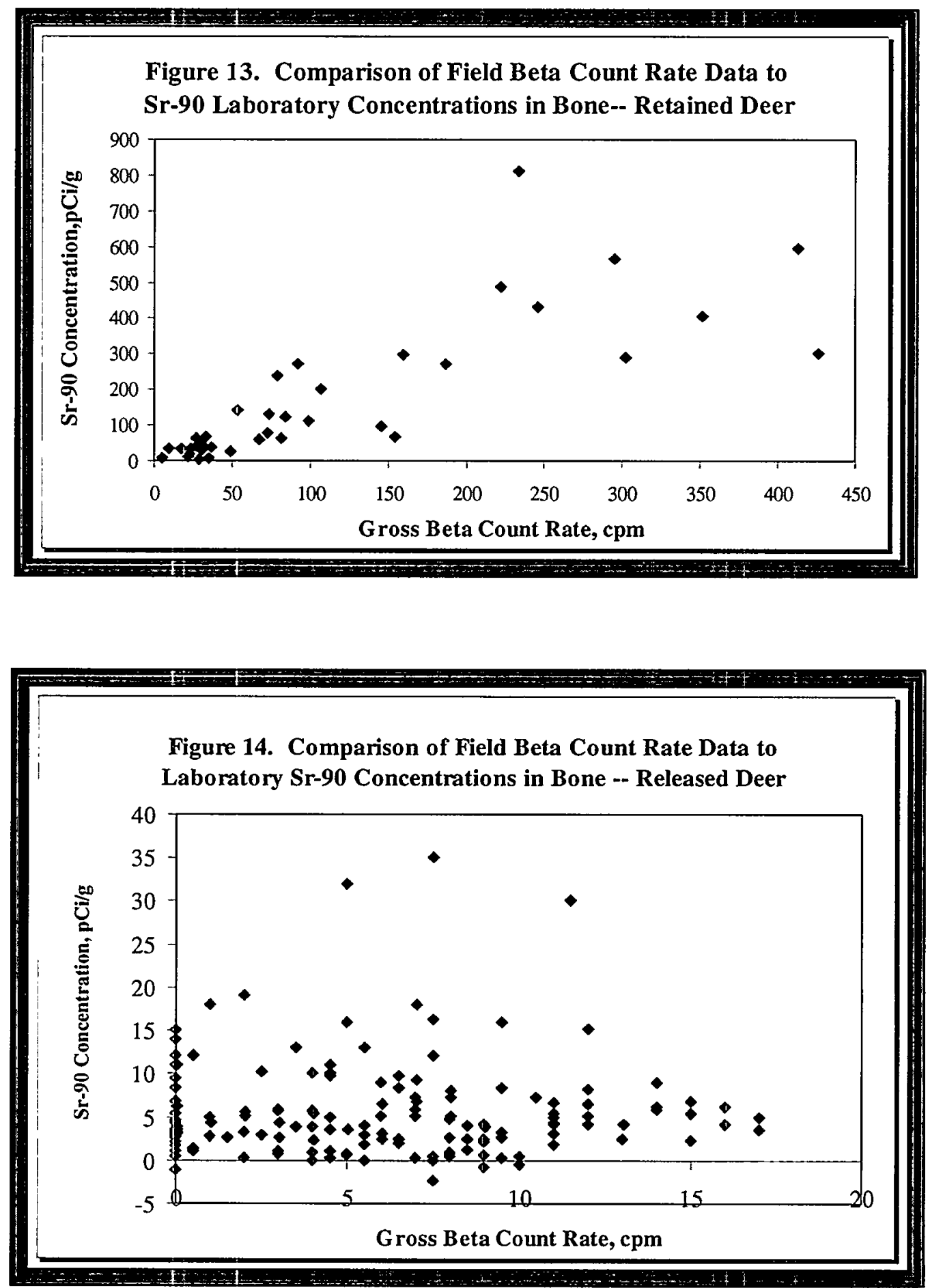


\subsection{Strontium-90 Concentrations in Tissue and Bone}

Since deer are retained primarily due to elevated beta particle activity in bone and the laboratory analytical results confirm that the beta particle activity is ${ }^{90} \mathrm{Sr}$, it is important to determine what the potential ${ }^{90} \mathrm{Sr}$ concentration is in edible tissue. Figure 15 represents ${ }^{90} \mathrm{Sr}$ concentrations in bone and tissue from both retained and released deer. In Figure 16, the measured ${ }^{90} \mathrm{Sr}$ concentrations in bone and tissue are given for released deer. As shown in both Figures 15 and 16, regardless of the ${ }^{90} \mathrm{Sr}$ concentration in bone (with one exception), the ${ }^{90} \mathrm{Sr}$ concentration in tissue has not exceeded about $3 \mathrm{pCi} / \mathrm{g}(0.1 \mathrm{~Bq} / \mathrm{g})$. In released deer (Figure 16),
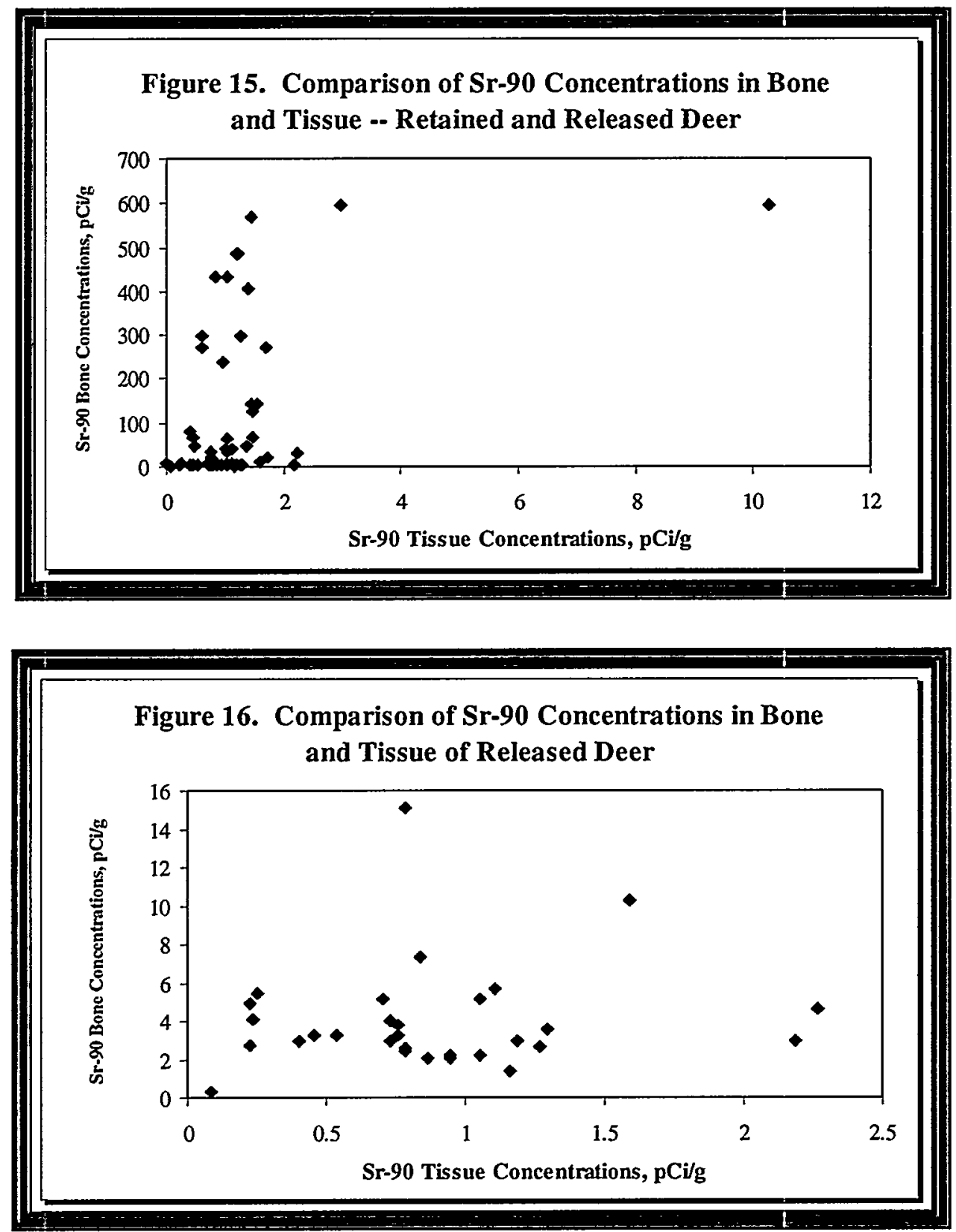
the ${ }^{90} \mathrm{Sr}$ concentration has never exceeded about $2.3 \mathrm{pCi} / \mathrm{g}(0.09 \mathrm{~Bq} / \mathrm{g})$. However, there are important issues to consider - ${ }^{90} \mathrm{Sr}$ concentrations in tissue were analyzed by two different methods. In 1990, 1991, 1992, and 1996 total radiostrontium concentrations in tissue were measured using a modified EPA method 905.0. In 1993, 1994, and $1995{ }^{90} \mathrm{Sr}$ was analyzed using a liquid scintillation direct counting method to analyze the Cerenkov radiation from the ${ }^{90} \mathrm{Y}$ assumed to be in equilibrium with the ${ }^{90} \mathrm{Sr}$ activity in the samples. This later technique proved to yield results that were questionable due to elevated backgrounds and potential interferences such as chemiluminescence in the liquid scintillation cocktail. These interferences may account for the apparently elevated ${ }^{90} \mathrm{Sr}$ concentrations observed in these samples. Eliminating the 1993, 1994, and $1995{ }^{90} \mathrm{Sr}$ concentrations tissue data set, the relationship of ${ }^{90} \mathrm{Sr}$ concentrations in tissue (modified EPA 905.0 method) to bone is shown in Figures 17 and 18 [Note: negative concentrations are results which are below background] .

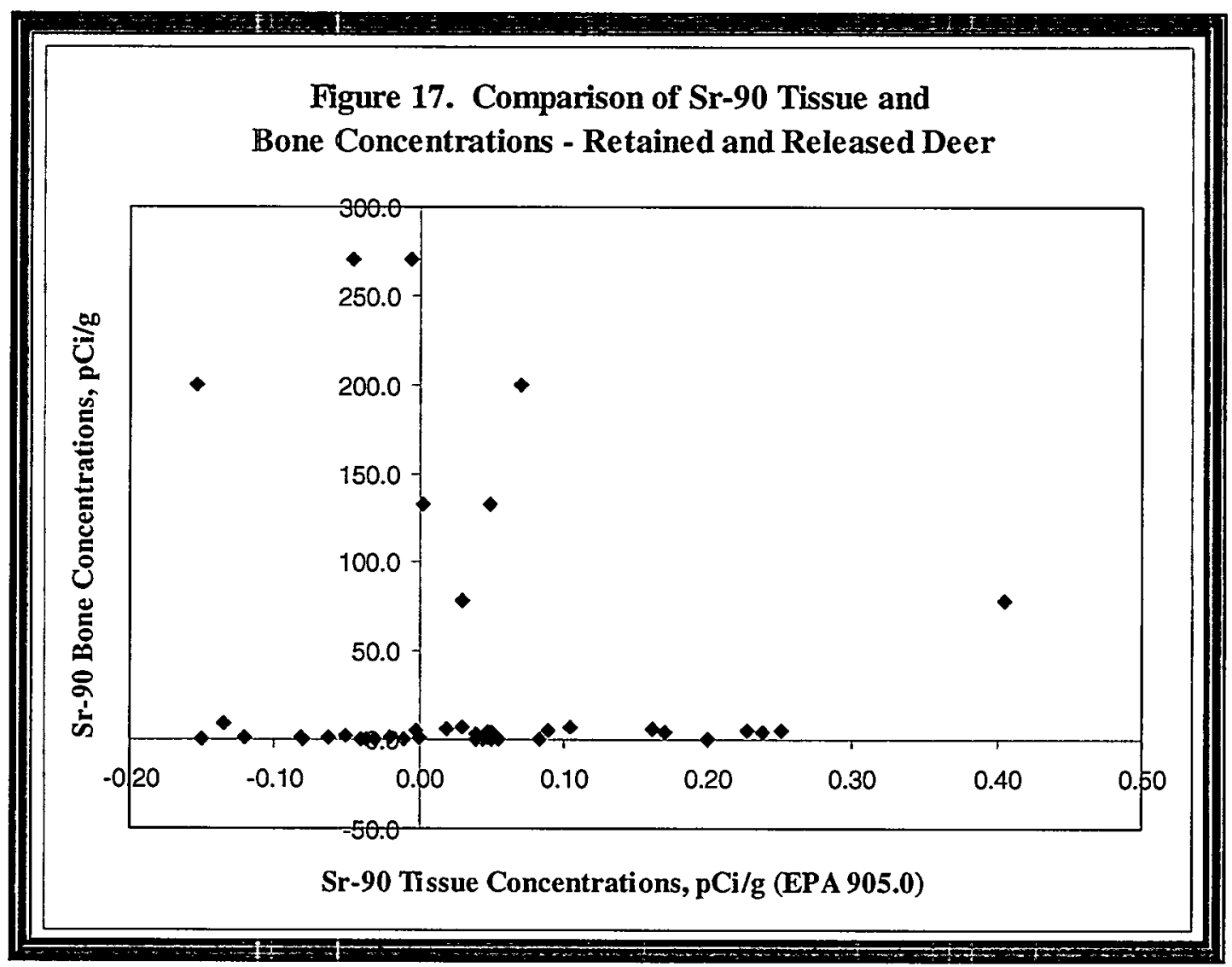




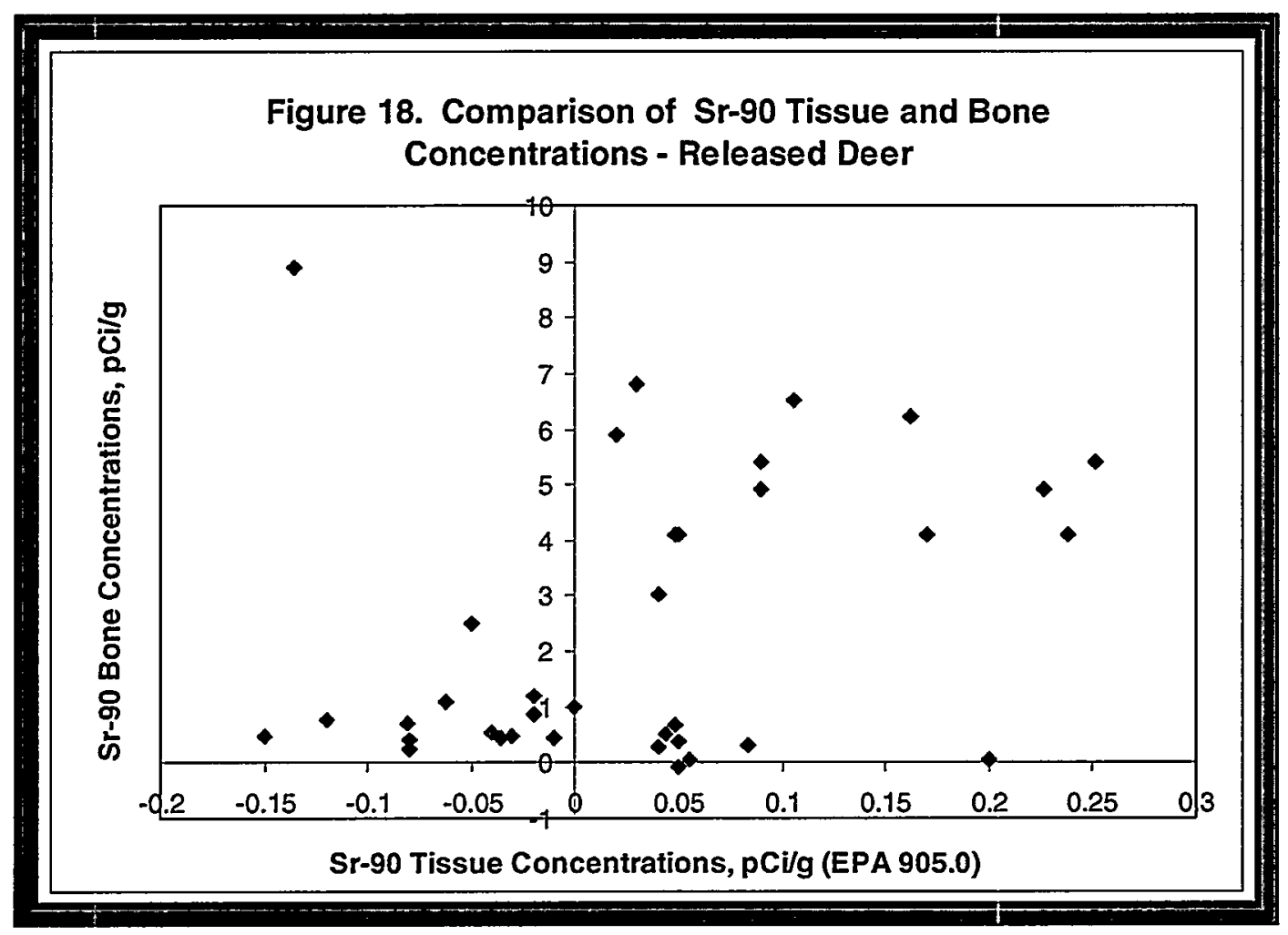

As shown in Figures 17 and 18 , the ${ }^{90} \mathrm{Sr}$ concentrations in tissue do not exceed about $0.4 \mathrm{pCi} / \mathrm{g}$ and $0.25 \mathrm{pCi} / \mathrm{g}$, respectively. Based on the elevated backgrounds associated with the previously mentioned liquid scintillation Cerenkov counting method (for tissue) and potential interferences such as chemiluminescence in the liquid, therefore, the data shown in Figures 17 and 18 are considered to represent actual ${ }^{90} \mathrm{Sr}$ concentrations in tissue.

There is not an obvious relationship between ${ }^{90} \mathrm{Sr}$ concentrations in bone and tissue, even after accounting for the age of the sampled deer. In the human body, after uptake, ${ }^{90} \mathrm{Sr}$ is initially distributed within the body and as time progresses, the ${ }^{90} \mathrm{Sr}$ collects in the bone (Leggett, 1997). There is also the effect of biological half-life of ${ }^{90} \mathrm{Sr}$ in bone and tissue. Based on the current tissue and bone ${ }^{90} \mathrm{Sr}$ concentration data, it is difficult to develop a representative tissue to bone $(\mathrm{T}: \mathrm{B})$ ratio (see Appendix D). The majority of tissue samples used in this analysis were liver. It is strongly recommended that additional muscle samples be collected and the ${ }^{90} \mathrm{Sr}$ concentrations in muscle and bone be further evaluated. 


\subsection{Radionuclide Concentrations in Deer Thyroid Glands}

Periodically over the years, thyroid samples have been collected and analyzed either at ORNL or by an off-site laboratory to determine if there is any on-site iodine contamination sources. Of the radioiodines, ${ }^{129} \mathrm{I}$ has been detected the most frequently in deer thyroid glands, followed by ${ }^{125}$ I and ${ }^{131}$ I. Cesium- 137 has occasionally also been detected in deer thyroid glands. Figure 19 is a summary of radioiodine concentrations detected in deer thyroid glands. In 1992, ${ }^{131} \mathrm{I}$ was detected in all eleven deer thyroid glands sampled, ${ }^{129} \mathrm{I}$ was detected in five thyroids, and ${ }^{137} \mathrm{Cs}$ was detected in seven of the thyroid glands. In 1994, nine retained and twelve released deer thyroids were analyzed for ${ }^{125} \mathrm{I},{ }^{129} \mathrm{I},{ }^{131} \mathrm{I},{ }^{133} \mathrm{I},{ }^{135} \mathrm{I}$, and ${ }^{137} \mathrm{Cs}$. Iodine- 129 was below the limit of detection in all but one of the thyroid glands, no ${ }^{131} \mathrm{I}$ was detected, and ${ }^{125} \mathrm{I}$ was detected in two thyroid glands. Cesium- 137 was detected in seven of the thyroids and in one case, a ${ }^{137} \mathrm{Cs}$ concentration of $2000 \mathrm{pCi} / \mathrm{g}$ was measured in one of the retained deer thyroids. In the same deer, the ${ }^{129} \mathrm{I}$ concentration was $220 \mathrm{pCi} / \mathrm{g}$. In $1995,{ }^{125} \mathrm{I},{ }^{129} \mathrm{I}$, and ${ }^{131} \mathrm{I}$ were measured in ten, six, and one thyroid glands, respectively. Cesium-137 was measured in five thyroid glands. In 1996, only ${ }^{129} \mathrm{I}$ was detected in the three thyroid glands sampled. In $1997,{ }^{129}$ I was detected in eight of the nine thyroids and ${ }^{125} \mathrm{I}$ was detected in four of the nine thyroids sampled. The highest radioiodine and cesium concentrations were detected in deer thyroid glands in 1994 and 1995. However, there does not appear to be a single source of iodine since these deer were harvested at different locations on the ORR.

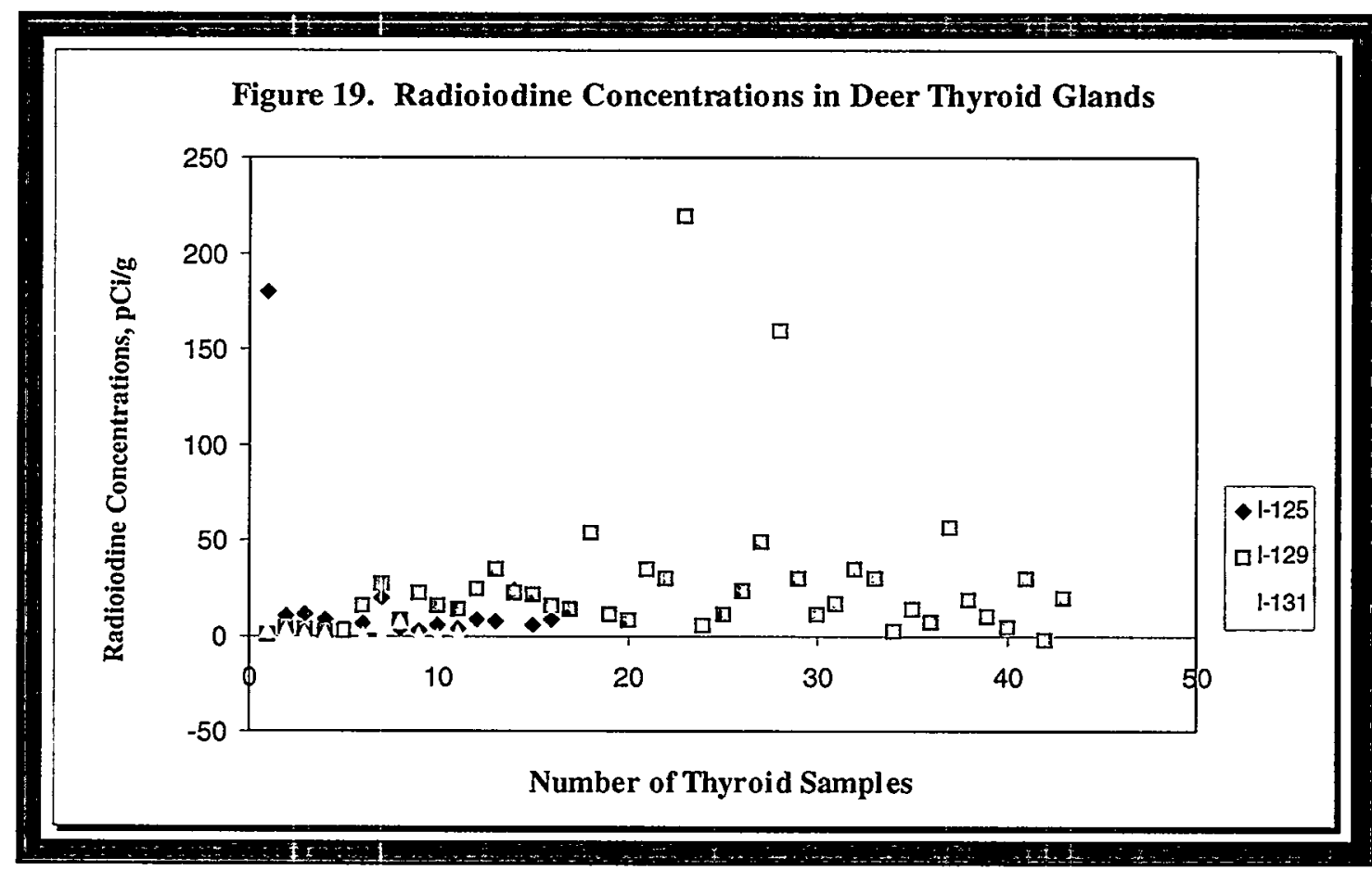




\subsection{Other Radionuclide Concentrations Detected in Deer Tissue}

Occasionally ${ }^{60} \mathrm{Co}$ has been detected in deer tissue. Figure 20 illustrates the ${ }^{60} \mathrm{Co}$ concentrations that have resulted in these samples [Note: negative concentrations are results which are below background]. Other than ${ }^{40} \mathrm{~K}$, no other radionuclides have been detected in deer tissue or bone samples.

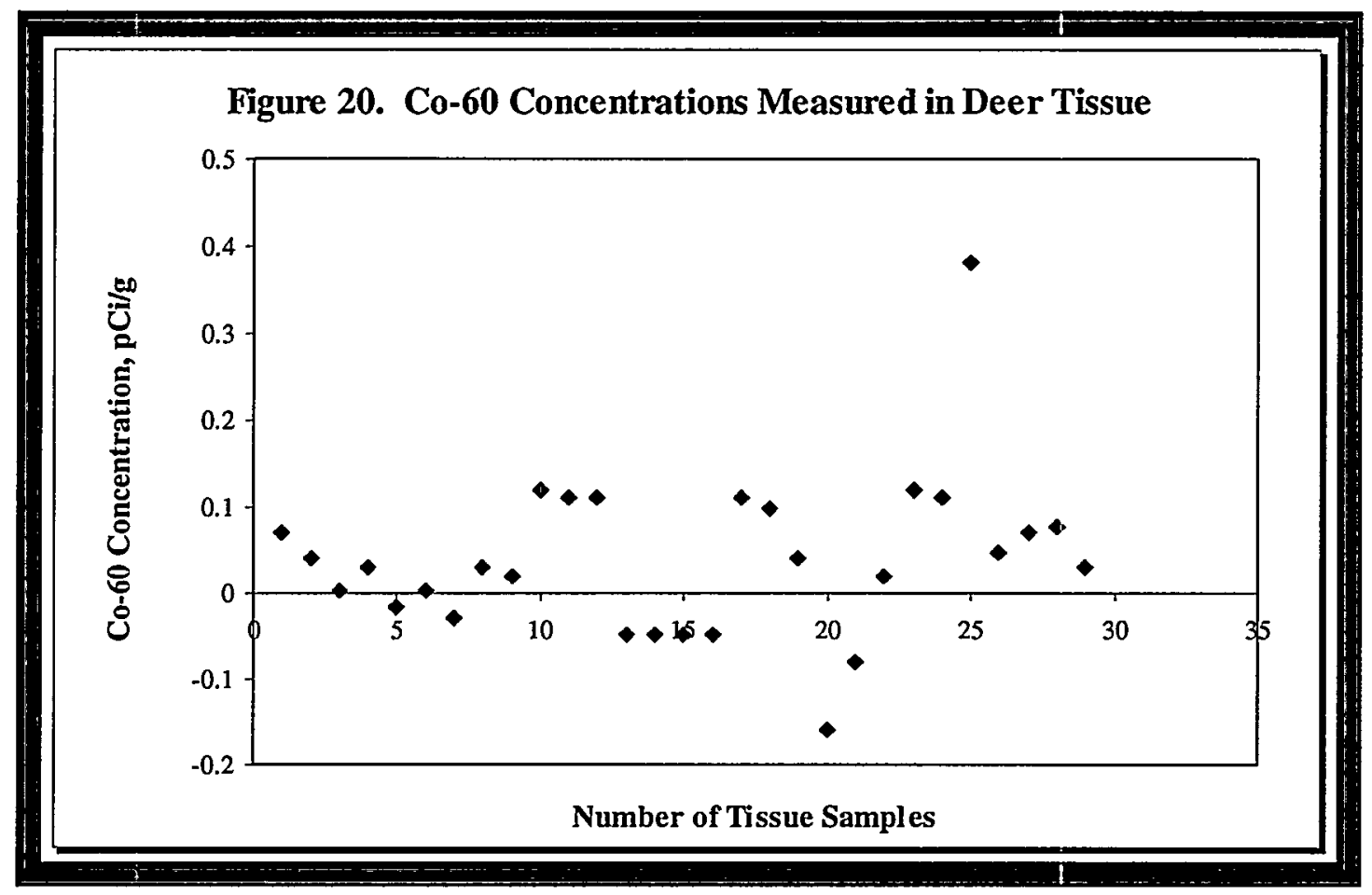

\subsection{Radionuclide Concentrations in Off-site Deer Tissue}

In 1994 muscle, liver, and bone samples were collected from four deer harvested in the Chuck Swan Wildlife Management Area. Chuck Swan is located near LaFollette, Tennessee, about 30 miles northeast of Oak Ridge. Though white tail deer are known to establish new territories and male deer are known to travel considerable distances during the rutting season, it is considered unlikely that deer harvested at Chuck Swan came from or spent time on the ORR. Radionuclide concentrations detected in these deer are summarized in Table 2. There was no significant difference between the liver and muscle ${ }^{137} \mathrm{Cs}$ concentrations measured in the off-site (background) deer and the deer released from the ORR (at 95\% CI). 
As mentioned in Section 3.4, the analytical method used to measure ${ }^{90} \mathrm{Sr}$ concentrations in tissue in 1993, 1994, and 1995 did not yield reliable results, therefore, the ${ }^{90} \mathrm{Sr}$ concentrations measured in the off-site deer were not comparable to ORR ${ }^{90} \mathrm{Sr}$ concentrations tissue data. It would be instructive to obtain additional deer samples from other areas remote from the ORR to further document background radionuclide concentrations found in deer tissue and bone samples.

Table 2. Analytical Results of Tissue and Bone Samples from Deer Harvested Off-site

\begin{tabular}{|c|c|c|c|c|}
\hline Deer & Radionuclide & $\begin{array}{c}\text { Muscle } \\
\text { concentration, } \\
\text { pCi/g }\end{array}$ & $\begin{array}{c}\text { Liver } \\
\text { Concentration, } \\
\text { pCi/g }\end{array}$ & $\begin{array}{c}\text { Bone } \\
\text { Concentration, } \\
\text { pCi/g }\end{array}$ \\
\hline \multirow[t]{3}{*}{ Background Deer 1} & ${ }^{137} \mathrm{Cs}$ & $0.3 \pm 0.14$ & $<0.22$ & \\
\hline & ${ }^{90} \mathrm{Sr}^{\mathrm{a}}$ & $1.2 \pm 0.16$ & $1.1 \pm 0.24$ & $4.3 \pm 0.54$ \\
\hline & ${ }^{40} \mathrm{~K}$ & $2.7 \pm 1.08$ & $2 \pm 1.16$ & \\
\hline \multirow[t]{3}{*}{ Background Deer 2} & ${ }^{137} \mathrm{Cs}$ & $0.27 \pm 0.06$ & $<0.19$ & \\
\hline & ${ }^{90} \mathrm{Sr}^{3}$ & $1.1 \pm 0.16$ & $0.68 \pm 0.24$ & $5.7 \pm 0.54$ \\
\hline & ${ }^{40} \mathrm{~K}$ & $4.3 \pm 1.08$ & $3 \pm 1.1$ & \\
\hline \multirow[t]{3}{*}{ Background Deer 3} & ${ }^{137} \mathrm{Cs}$ & $<0.27$ & 0.035 & \\
\hline & ${ }^{90} \mathrm{Sr}^{3}$ & $1.1 \pm 0.19$ & $0.7 \pm 0.19$ & $4.1 \pm 0.54$ \\
\hline & ${ }^{40} \mathrm{~K}$ & $3.8 \pm 1.35$ & $2.7 \pm 0.81$ & \\
\hline \multirow[t]{3}{*}{ Background Deer 4} & ${ }^{137} \mathrm{Cs}$ & $0.32 \pm 0.14$ & $<0.14$ & \\
\hline & ${ }^{90} \mathrm{Sr}^{9}$ & $1.2 \pm 0.19$ & $0.77 \pm 0.16$ & $5.7 \pm 0.81$ \\
\hline & ${ }^{40} \mathrm{~K}$ & $2.7 \pm 1.08$ & $2.5 \pm 0.78$ & \\
\hline
\end{tabular}

${ }^{a}$ Strontium-90 was measured by the Cerenkov method. See earlier discussion on ${ }^{90} \mathrm{Sr}$ concentrations in tissue. 


\section{SECTION 4. EFFECTIVE DOSE EQUIVALENT ESTIMATES}

An ORR hunter survey was conducted December 13-14, 1997 (Grainger, 1997). Seventy hunters were surveyed. All hunters surveyed indicated that $100 \%$ of the venison harvested was eaten either by immediate household members or given to other individuals for consumption. Approximately $76 \%$ of the hunters surveyed keep $80 \%$ or more of the harvested venison for consumption by the immediate household. Thirty percent of the hunters considered themselves to be the primary consumers of the venison and about $44 \%$ included themselves, wives, and children as the primary consumers of the venison. Therefore, it is important to evaluate the potential effective dose equivalents (EDEs) associated with the consumption of venison harvested on the ORR.

All of the deer harvested on the ORR have been field screened for beta and gamma (specifically ${ }^{137} \mathrm{Cs} /{ }^{137 \mathrm{~m}} \mathrm{Ba}$ ) contamination. Field ${ }^{137} \mathrm{Cs}$ analyses and laboratory analysis of other radionuclides $\left({ }^{90} \mathrm{Sr}\right)$ have been used to estimate maximum individual effective dose equivalents to hunters who have consumed venison from harvested deer from the ORR. Collective effective dose equivalents have been estimated.

\subsection{Maximum Individual Effective Dose Equivalents}

Potential committed effective dose equivalent (EDE) to hunters who ingested the maximum amount ${ }^{137} \mathrm{Cs}$ and ${ }^{90} \mathrm{Sr}$ from venison harvested on the ORR are shown in Figure 21. The amount of ${ }^{137} \mathrm{Cs}$ ingested per deer was sorted by year to identify highest annual ${ }^{137} \mathrm{Cs}$ intake values. The amount of ${ }^{137} \mathrm{Cs}$ ingested was estimated by multiplying the actual field ${ }^{137} \mathrm{Cs}$ concentrations by the field dressed weights of each deer harvested and by 55\%, which accounts for the amount of edible meat obtained from field dressed deer (Adams Taxidermy and Deer Processing, 1992). Since ${ }^{90} \mathrm{Sr}$ concentrations in tissue were not measured in every deer, the maximum ${ }^{90} \mathrm{Sr}$ tissue concentration of $0.4 \mathrm{pCi} / \mathrm{g}$ and the actual field dressed weights were also used to estimate intake values and EDEs. It was conservatively assumed that an individual consumes all of the venison from one deer. As shown in Figure 21, the maximum EDE from consumption of venison from a deer released from the ORR (1990-1997) could have been about 5 mrem.

A hunter is allowed to harvest no more than two deer in one year from the ORR. In Figure 22 are the estimated EDEs for eight cases in which two deer were harvested by a hunter or two to three deer were harvested by members of the same household. Actual field ${ }^{137} \mathrm{Cs}$ concentrations, the maximum ${ }^{90} \mathrm{Sr}$ concentration of $0.4 \mathrm{pCi} / \mathrm{g}$, and actual field dressed weights were used to estimate EDEs. It was conservatively assumed that an individual consumes all of the venison obtained from two or three deer. The maximum EDE to an individual consuming two to three deer harvested from the ORR was estimated to be about $2 \mathrm{mrem}$. The variation in EDEs is due to ${ }^{137} \mathrm{Cs}$ concentration and deer weight differences. 


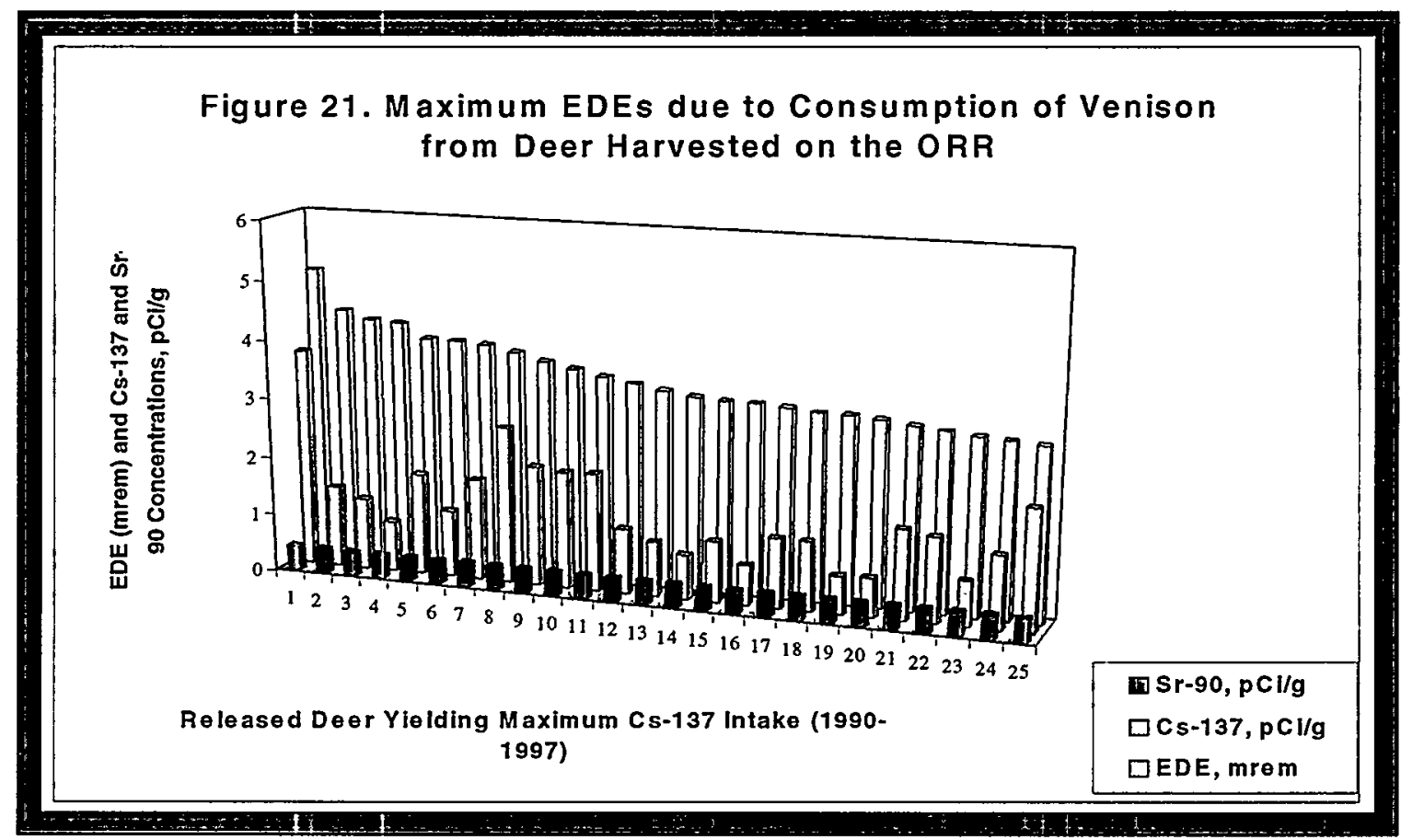

Figure 22. Estimated EDEs for Hunter/Households which Harvested Two or Three Deer in One Year

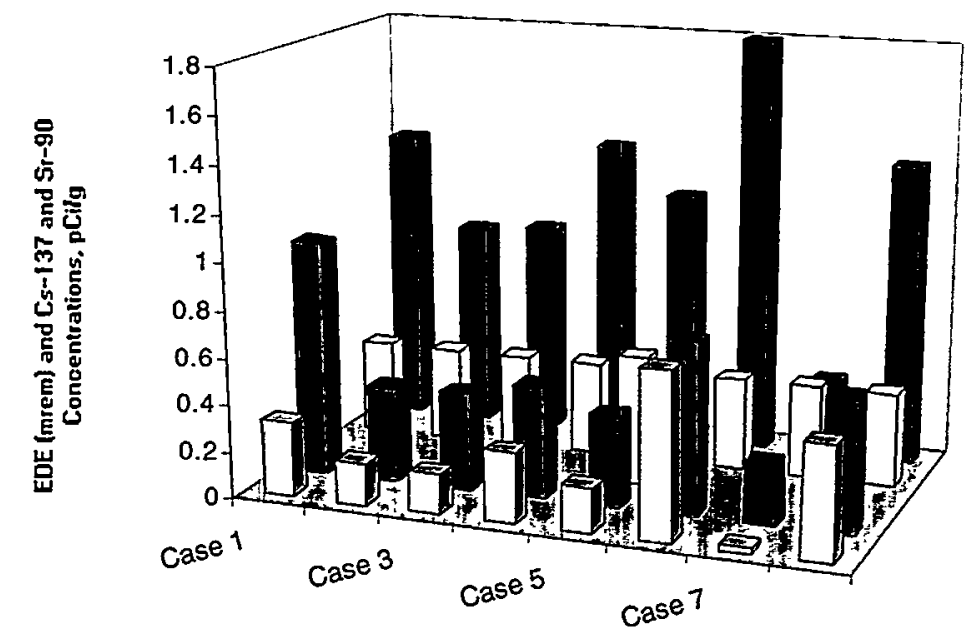

Hunter/Households 
In addition, thirteen years of data were reviewed, based on name and address, to see how many deer have been harvested on the ORR per household per year and if the same individuals hunted on the ORR year after year. Some key facts emerged when evaluating the hunter data:

- Overall, there are usually two or less deer harvested per household per year.

- There have been two cases in which four deer have been harvested by hunters from the same household during the same year.

- No single hunter has hunted on the ORR more than 4 years, and no single hunter has retained more than four deer over thirteen years of the ORR deer hunts.

- The greatest number of deer harvested on the ORR by a household has been nine.

In the two cases in which four deer were harvested by hunters in the same household in the same year, the total EDE to an individual consuming all of the edible deer meat (based on field ${ }^{137} \mathrm{Cs}$ concentrations and maximum ${ }^{90} \mathrm{Sr}$ concentration) were both about $6 \mathrm{mrem}$. In the one case, where 9 deer (four in 1988, two in 1992, and one deer in 1993, 1994, and 1996) were harvested by hunters in the same household, the total EDE from consumption of the edible deer meat by one individual would be about $10 \mathrm{mrem}$.

\subsection{Collective Effective Dose Equivalent}

The collective EDE is calculated by taking the average field ${ }^{137} \mathrm{Cs}$ concentration and average measured ${ }^{90} \mathrm{Sr}$ concentrations in tissue of released deer and multiplying by the total number of deer released, by the average field dressed deer weight, and by $55 \%$ which accounts for the amount of available edible meat. The radionuclide concentrations and the associated annual collective doses are summarized in Figure 23. The annual collective EDEs range from about 0.03 to 3 person-rem. As discussed in section 3.4, the ${ }^{90} \mathrm{Sr}$ concentrations in tissue were elevated in 1994 and 1995. These ${ }^{90} \mathrm{Sr}$ concentrations were elevated due to interferences in the analysis rather than to actual elevated ${ }^{90} \mathrm{Sr}$ concentrations in tissue. 


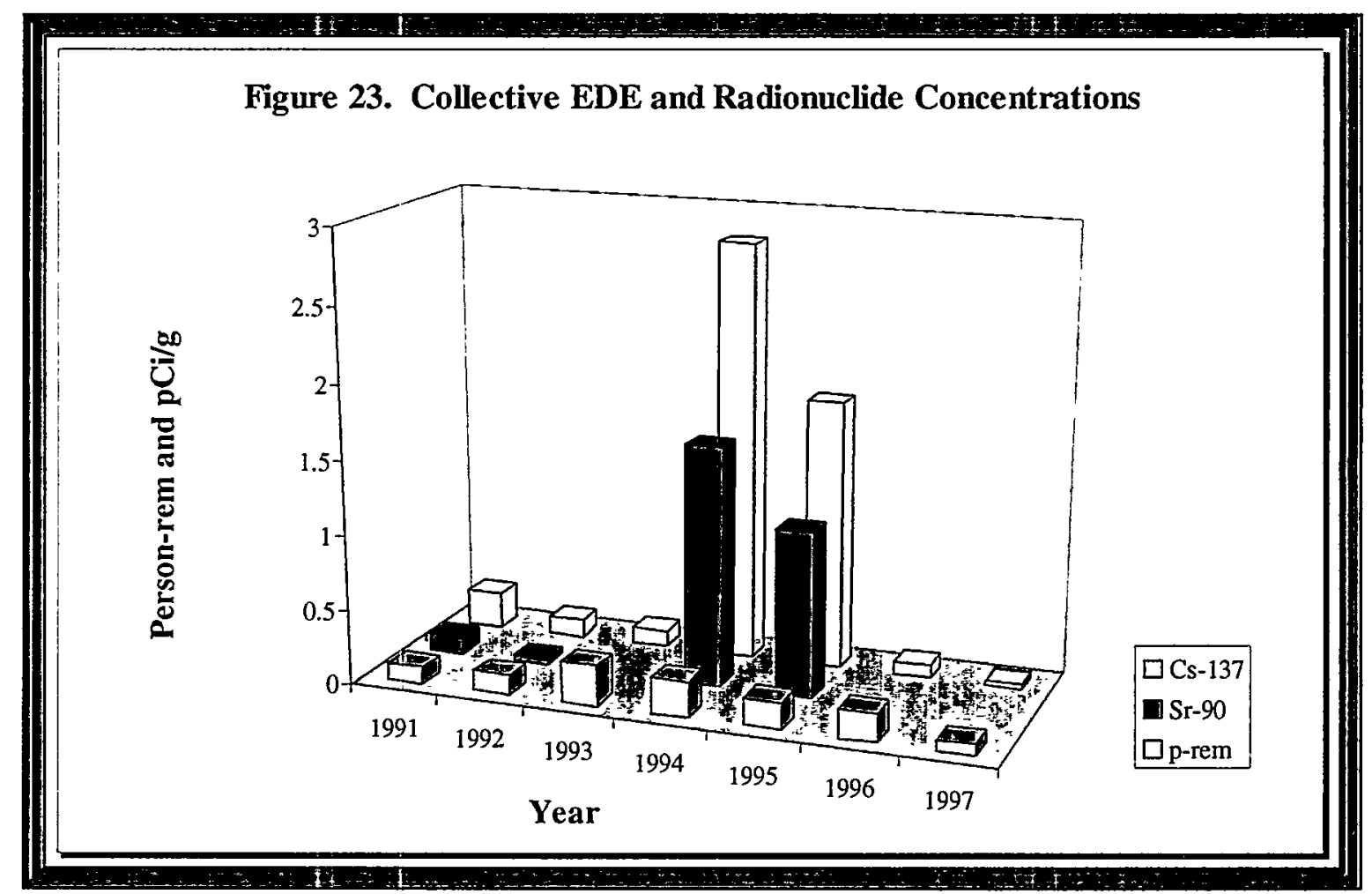




\section{SECTION 5. VEHICULAR ACCIDENT RISKS}

Deer hunts were initiated to reduce the number of vehicular accidents caused by deer. Figure 24 provides information on the number of deer that have been killed annually by vehicles. In 1995, 150 deer were killed in vehicular collisions. In 1996 and 1997, 106 deer and 91 deer were killed in vehicular collisions, repectively. The decrease in the number of deer killed in 1996 and 1997 does not reflect an actual reduction in the number of deer killed but rather a reduction in the counting area (Evans, 1998). To estimate the potential risk of hitting and killing a deer on the road and comparing risks from the hunt initiation to present, Tennessee Department of Transportation 1985 and 1996 average daily travel volume on state and local roads data were used. The 1985 and 1996 daily vehicular volume on state roads surrounding and crossing the ORR are estimated to be about 51,274 and 74,500 , respectively.

The annual vehicle volumes are estimated to be approximately 1.9 million and 2.7 million, respectively. In 1985, when the deer hunt was initiated, the risk of hitting and killing a deer with a vehicle was about $1.5 \times 10^{-5}$. In 1996, the risk of hitting and killing a deer with a vehicle decreased to about $4 \times 10^{-6}$. Since there was a change in road kill enumeration starting in 1996, the risk of hitting a deer may be slightly greater. It is very likely that deer have been hit but not immediately killed (moved into undercover). It is unknown how many cases there have been, but if it is assumed that an additional 30 percent more deer were killed than have been enumerated as road kills, the risk of hitting a deer (and potentially causing vehicular damage) increases to about $2 \times 10^{-5}$ and $5 \times 10^{-6}$, respectively.

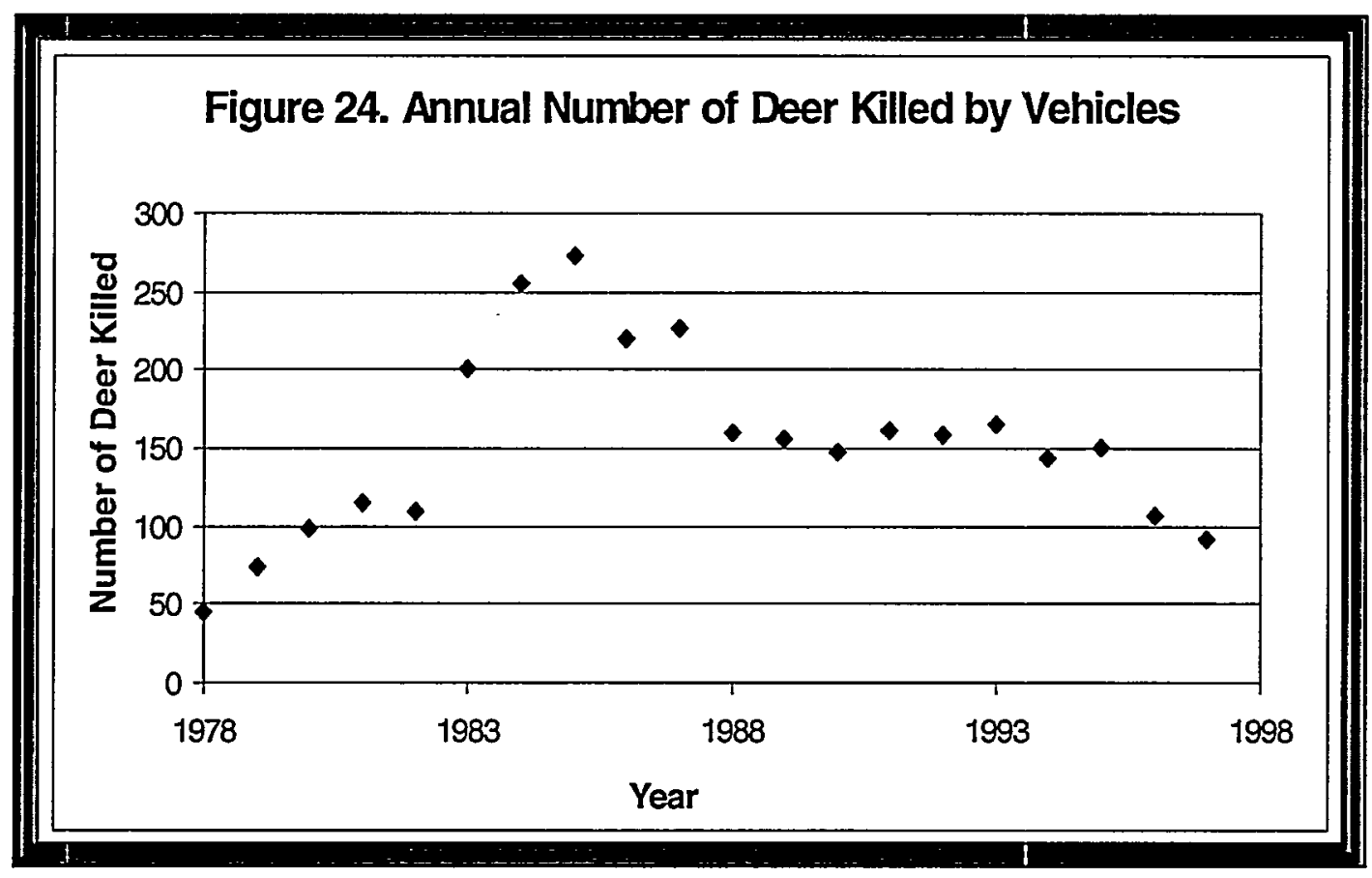




\section{SECTION 6. CONCLUSION AND RECOMMENDATIONS}

The primary purpose of the deer hunts is to maintain a healthy herd and protect public safety in areas surrounding the ORR. Based on the harvest data presented in Section 2, it appears that the population has remained steady since about 1987, two years after the inception of the deer hunts on the ORR. In allowing deer hunts on the ORR, a deer hunt monitoring program was established to insure that deer were not released to the general public above the administrative deer release limits established for the ORNL. A two component monitoring program was established to achieve this goal - first a field monitoring program was established to radiologically check each deer harvested on the ORR to quickly determine whether deer should be released. Secondly, as a quality control measure and to confirm the field screening program, selected deer tissue and bone samples have been analyzed in the laboratory.

Based on evaluation of the deer hunt monitoring program data, the following conclusions can be made:

- There are about three areas of the ORR, west of ORNL, in which the percentage of retained deer is greater than or equal to $5 \%$. There is one area $(06 \mathrm{G})$ from which about $22 \%$ of the deer harvested over a thirteen year period has been retained.

- In all cases, field ${ }^{137} \mathrm{Cs}$ analyses (when compared to ${ }^{137} \mathrm{Cs}$ laboratory analyses) were capable of determining if ${ }^{137} \mathrm{Cs}$ concentrations in tissue met or exceeded the administrative limit.

- There is very good agreement between the field (cpm) screening of bone to measured ${ }^{90} \mathrm{Sr}$ concentrations in bone. A linear expression fits the data, resulting in an equation that can be used to provide an estimate of the ${ }^{90} \mathrm{Sr}$ concentration in bone from field gross beta measurements. The field gross beta count rate measurement method has been capable of detecting ${ }^{90} \mathrm{Sr}$ in bone, so that in the majority of cases, deer have not been released above the administrative limits.

- There is not a good correlation between the ${ }^{90} \mathrm{Sr}$ concentrations in bone to ${ }^{90} \mathrm{Sr}$ concentrations in tissue. This discrepancy may be due to partitioning of strontium throughout the body and is related to the time of intake and harvesting as well as the biological half-life of the radionuclide. However, regardless of the ${ }^{90} \mathrm{Sr}$ concentrations measured in bone, the maximum ${ }^{90} \mathrm{Sr}$ muscle concentration (with one exception) has not exceeded about $0.4 \mathrm{pCi} / \mathrm{g}$ (omission of 1993, 1994, and 1995 data due to previously mentioned interferences) .

- Other radionuclides have been detected in deer harvested from the ORR -- most notably ${ }^{129} \mathrm{I}$ and ${ }^{131} \mathrm{I}$ in the thyroid glands and ${ }^{60} \mathrm{Co}$ in tissue. Iodine- 129 has been the most frequently detected radioiodine. Cobalt- 60 has been infrequently detected. 
detected.

- Cesium-137 concentrations detected in tissue samples from deer collected at "background" locations were very similar to concentrations measured in deer released from the ORR.

- In a survey conducted in 1997 , approximately $76 \%$ of the hunters said that they kept $80 \%$ or more of the venison, which was consumed by the immediate household. Thirty percent of the hunters surveyed considered themselves to be the primary consumers of the venison.

- The potential maximum individual EDE from consumption of venison from deer harvested on the ORR could have been about 5 mrem. This EDE assumes that ${ }^{90} \mathrm{Sr}$ in tissue was at the maximum concentration of $0.4 \mathrm{pCi} / \mathrm{g}$. Estimated EDEs to selected hunters consuming venison from two or three actual deer harvested from the ORR ranged from about $0.3 \mathrm{mrem}$ to $1.6 \mathrm{mrem}$. In two cases where four deer were harvested in one year by members of the same household, the estimated EDE for an individual who consumed all of the venison from the four deer was estimated to be about 6 mrem. In the one case where nine deer were harvested from the ORR by members of the same household (over a number of years), the estimated EDE to an individual that consumed all of the venison is 10 mrem. Estimated collective EDEs per annual harvest range from about 0.03 person-rem to 3 person-rem.

- Some basic deer hunting characteristics have emerged when examining the annual deer harvesting data. Hunters have not hunted on the ORR more than four years and most hunters and hunter households harvest from the ORR two or less deer per year.

- In 1985, when the deer hunts were initiated, the risk of hitting and killing a deer with a vehicle was about $1.5 \times 10^{-5}$. In 1996 , the risk of hitting and killing a deer with a vehicle decreased to about $4 \times 10^{-6}$. It is likely that there are cases in which deer have been hit but not immediately killed (moved into undercover). It is unknown how many cases there have been, but if it is assumed that an additional thirty percent of deer have been killed than have been enumerated as road kills, the risk of hitting a deer (and potentially causing vehicular damage) increases to about $2 \times 10^{-5}$ and $5 \times 10^{-6}$, respectively. 
In reviewing the deer hunt monitoring data between the years of 1985 and 1997, it is recommended that -.

- The two component program -- field screening with confirmatory laboratory analyses remain in place. It is strongly recommended that routine laboratory analyses be conducted not only on retained deer but on tissue samples from deer released from the ORR.

- Muscle samples should be used for analyses rather than liver samples; data show that a greater concentration of ${ }^{137} \mathrm{Cs}$ in muscle as compared to liver.

- The Cerenkov methodology should not be used to measure radiostrontium in tissue samples. Based on experience, interferences associated with this methodology resulted in greater ${ }^{90} \mathrm{Sr}$ concentrations than were actually in the tissue.

- It is strongly recommended that additional muscle and bone samples be collected and analyzed for ${ }^{90} \mathrm{Sr}$. The purpose of this analyses is to evaluate if there is any relationship between ${ }^{90} \mathrm{Sr}$ in tissue and bone. If there is no observable relationship, then it may be important to reevaluate the purpose of the gross beta activity field measurement, as well as, to evaluate the range and maximum ${ }^{90} \mathrm{Sr}$ concentrations observed in deer tissue harvested from the ORR.

- In areas on the ORR in which a greater percentage of deer are being retained, potential sources of contamination need to be identified.

- A limited study should be conducted to evaluate if deer have been exposed to chemical contaminants on the ORR. 


\section{SECTION 7. REFERENCES}

Adams Taxidermy and Deer Processing, Personal communication, 1992.

Evans, James, Tennessee Wildlife Resources Agency, Personal communication, 1998.

Grainger, Chris, December 13 and 14, 1997 Deer Hunt Survey Results, Roane State Community College, 1997.

Halls, L. K., White Tailed Deer Ecology and Management, A Wildlife Management Institute Book, Stackpole Books, Harrisburg, PA, 1984.

Leggett, Richard, Personal communication, Life Sciences Division, Oak Ridge National Laboratory, 1997. 


\section{APPENDICES}

Appendix A: Mean Field ${ }^{137} \mathrm{Cs}$ Concentrations Summary

Appendix B: Field and Laboratory ${ }^{137} \mathrm{Cs}$ Concentration Tables

Appendix C: Beta Count Rate and ${ }^{90} \mathrm{Sr}$ Concentrations in Bone

Appendix D: ${ }^{90} \mathrm{Sr}$ Concentrations in Tissue and Bone 
Appendix A: Mean Field ${ }^{137}$ Cs Concentration Summary

\begin{tabular}{|ccccc|}
\hline Year & N & $\begin{array}{c}\text { Retained Deer } \\
\text { Number }\end{array}$ & $\begin{array}{c}\text { Mean Cs-137 } \\
\text { Released Deer } \\
(\mathbf{p C i} / \mathrm{g})\end{array}$ & $\begin{array}{c}\text { Mean Cs-137 } \\
\text { Retained } \\
(\mathbf{p C i} / \mathrm{g})\end{array}$ \\
\hline $\mathbf{1 9 8 5}$ & 925 & 7 & None Available & None Available \\
$\mathbf{1 9 8 6}$ & 660 & 29 & 0.18 & 0.24 \\
1987 & 530 & 30 & 0.14 & 0.04 \\
$\mathbf{1 9 8 8}$ & 507 & 13 & 0.23 & 0.19 \\
$\mathbf{1 9 8 9}$ & 440 & 21 & -0.05 & 0.09 \\
1990 & 442 & 6 & 0.07 & -0.02 \\
$\mathbf{1 9 9 1}$ & 476 & 7 & 0.11 & 0.28 \\
1992 & 520 & 12 & 0.13 & 0.27 \\
1993 & 400 & 7 & 0.27 & 0.30 \\
1994 & 495 & 8 & 0.24 & 94.89 \\
1995 & 489 & 8 & 0.18 & 0.30 \\
1996 & 464 & 2 & 0.19 & 0.05 \\
1997 & 438 & 9 & 0.07 & 0.03 \\
\hline
\end{tabular}

A-1 


\section{Appendix B: Field and Laboratory ${ }^{137} \mathrm{Cs}$ Concentration Tables}

\begin{tabular}{|c|c|c|c|}
\hline $\begin{array}{c}1990 \\
\text { Deer } \\
\text { No. }\end{array}$ & $\begin{array}{c}\text { Field } \\
\text { Cs-137 } \\
\text { pCi/g }\end{array}$ & $\begin{array}{c}\text { Muscle } \\
\text { Cs-137 } \\
\text { pCi/g }\end{array}$ & $\begin{array}{c}\text { Liver } \\
\text { Cs-137 } \\
\text { pCi/g }\end{array}$ \\
\hline $163 \mathrm{C}$ & -0.29 & $\overline{0.06}$ & -0.10 \\
\hline $189 \mathrm{C}$ & -0.08 & 0.14 & 0.05 \\
\hline $277 \mathrm{C}$ & -0.17 & 0.46 & -0.10 \\
\hline
\end{tabular}

\begin{tabular}{|cccc|}
\hline $\begin{array}{c}1991 \\
\text { Deer } \\
\text { No. }\end{array}$ & $\begin{array}{c}\text { Field } \\
\text { Cs-137 } \\
\text { pCi/g }\end{array}$ & $\begin{array}{c}\text { Muscle } \\
\text { Cs-137 } \\
\text { pCi/g }\end{array}$ & $\begin{array}{c}\text { Liver } \\
\text { Cs-137 } \\
\text { pCi/g }\end{array}$ \\
\hline \hline 1 & -0.05 & & -0.19 \\
7 & 0.03 & & 0.11 \\
$8 \mathrm{c}$ & 0.19 & 0.21 & 0.12 \\
10 & 0.06 & 0.19 & \\
13 & 0.12 & & 0.26 \\
18 & 0.03 & & 0.01 \\
35 & 0.42 & & 0.11 \\
53 & 0 & 0.14 & \\
59 & 0.3 & 0.01 & \\
$63 \mathrm{c}$ & 0.93 & 0.07 & -0.05 \\
64 & -0.22 & & -0.03 \\
88 & -0.1 & & -0.03 \\
103 & 0.36 & & -0.11 \\
134 & 0.02 & & 0.11 \\
136 & -0.07 & & 0.05 \\
140 & 0.11 & 0.11 & \\
\hline
\end{tabular}

B-1 


\begin{tabular}{|cccc|}
\hline $\begin{array}{c}1992 \\
\text { Deer } \\
\text { No. }\end{array}$ & $\begin{array}{c}\text { Field } \\
\text { Cs-137 } \\
\text { pCi/g }\end{array}$ & $\begin{array}{c}\text { Muscle } \\
\text { Cs-137 } \\
\text { pCi/g }\end{array}$ & $\begin{array}{c}\text { Liver } \\
\text { Cs-137 } \\
\text { pCi/g }\end{array}$ \\
\hline \hline 1 & 0.32 & & 0.092 \\
7 & 0.47 & & 0.12 \\
8 & 0.12 & & 0.06 \\
18 & 0.36 & 0.38 & \\
23 & 0.77 & 0.57 & \\
49 & 0.22 & 0.11 & \\
58 & 0.17 & & 0.18 \\
64 & 0.57 & 0.12 & \\
68 & 0.19 & & 0.46 \\
104 & 0.48 & & 0.43 \\
110 & -0.12 & & 0.04 \\
111 & 0.55 & & 0.46 \\
113 & 0.59 & & 0.046 \\
127 & 0.4 & 0.35 & \\
\hline
\end{tabular}

\begin{tabular}{|c|c|c|c|}
\hline $\begin{array}{c}1993 \\
\text { Deer } \\
\text { No. }\end{array}$ & $\begin{array}{c}\text { Field } \\
\text { Cs-137 } \\
\text { pCi/g }\end{array}$ & $\begin{array}{c}\text { Muscle } \\
\text { Cs-137 } \\
\text { pCi/g }\end{array}$ & $\begin{array}{c}\text { Liver } \\
\text { Cs-137 } \\
\text { pCi/g }\end{array}$ \\
\hline 2 & 0.36 & & 0.07 \\
\hline 6 & 0.21 & & 0.95 \\
\hline 13 & 0.31 & & 0.13 \\
\hline $21-C$ & 0.43 & & \\
\hline 33 & 0.35 & & 0.08 \\
\hline 73 & 1 & & missing data \\
\hline $75-C$ & 1 & 0.17 & -0.03 \\
\hline 81 & 0.72 & & 0.26 \\
\hline 99 & 0.21 & & 0.14 \\
\hline 102 & 0.16 & & 0.21 \\
\hline 122 & 0.08 & & 0.00 \\
\hline 123 & 0.36 & 0.30 & 0.11 \\
\hline 163 & 0 & & 0.05 \\
\hline 200 & -0.28 & & -0.01 \\
\hline 215 & 0.3 & & 0.02 \\
\hline 227 & 0.27 & & 0.08 \\
\hline 261 & -0.1 & 0.16 & -0.01 \\
\hline 268 & -0.02 & & -0.02 \\
\hline 273 & 0.26 & & 0.11 \\
\hline 278 & -0.01 & 0.17 & 0.07 \\
\hline 300 & 0.13 & & 0.07 \\
\hline 315 & 0.16 & & 0.11 \\
\hline 317 & 0.07 & 0.07 & 0.01 \\
\hline 333 & 0.39 & & 0.07 \\
\hline $340-\mathrm{C}$ & 0.17 & 0.06 & -0.01 \\
\hline 385 & 0.27 & & 0.04 \\
\hline
\end{tabular}

B-2 


\begin{tabular}{|c|c|c|c|}
\hline $\begin{array}{c}1994 \\
\text { Deer } \\
\text { No. }\end{array}$ & $\begin{array}{c}\text { Field } \\
\mathrm{Cs}-137 \\
\mathrm{pCi} / \mathrm{g}\end{array}$ & $\begin{array}{l}\text { Muscle } \\
\text { Cs-137 } \\
\text { pCi/g }\end{array}$ & $\begin{array}{c}\text { Liver } \\
\text { Cs-137 } \\
\text { pCi/g } \\
\end{array}$ \\
\hline 7 & 0.06 & 0.84 & 0.15 \\
\hline 8 & 1.21 & & 0.30 \\
\hline 9 & 0.05 & & 0.14 \\
\hline 35 & 0.13 & & 0.21 \\
\hline 77 & -0.16 & & 0.05 \\
\hline 92 & 0.45 & 0.14 & $<0.16$ \\
\hline 100 & 0.55 & $\begin{array}{c}<0.22 \\
0.10\end{array}$ & \\
\hline 102 & 0.75 & & 0.38 \\
\hline 110 & 1.53 & $\begin{array}{l}0.89 \\
1.20\end{array}$ & \\
\hline 117 & -0.22 & & 0.08 \\
\hline 120 & -0.24 & & 0.09 \\
\hline 139 & -0.01 & & 0.11 \\
\hline 143 & 0.14 & & 0.09 \\
\hline 145 & 0.07 & 0.17 & 0.05 \\
\hline 147 & -0.04 & $<0.022$ & 0.04 \\
\hline 157 & 0.4 & 19.00 & 1.00 \\
\hline 174 & 0.14 & 4.10 & 1.20 \\
\hline 175 & 0.16 & 0.27 & 0.89 \\
\hline 181 & 0.21 & 3.00 & 0.95 \\
\hline 220 & 0.04 & 2.70 & 0.81 \\
\hline $231-C$ & 0.17 & 0.12 & 0.10 \\
\hline 247 & 0.34 & & 1.20 \\
\hline $248-\mathrm{C}$ & 0.41 & 0.76 & 0.13 \\
\hline 253 & 0.01 & & \\
\hline 283-C & 17.3 & 26.00 & \\
\hline $289-C$ & 0.04 & 0.01 & $<0.22$ \\
\hline $291-C$ & 0.52 & 0.19 & $<0.22$ \\
\hline 308 & 0.33 & & 0.92 \\
\hline 319 & 1.98 & & 1.00 \\
\hline 341 & 1.14 & & 0.97 \\
\hline 347 & 1.72 & & 0.89 \\
\hline 353 & 0.54 & & 1.10 \\
\hline 388 & 0.11 & 1.20 & \\
\hline 405 & 0.89 & 1.60 & 0.81 \\
\hline 406 & 0.85 & 2.70 & 0.76 \\
\hline $409-C$ & 740 & 1200.00 & 860.00 \\
\hline 412 & 0.23 & & $<0.54$ \\
\hline 418 & 0.62 & 0.09 & \\
\hline $429-C$ & 0.38 & 0.07 & 0.11 \\
\hline 435 & 0.49 & & $<0.24$ \\
\hline $441-C$ & 0.31 & 0.10 & \\
\hline 451 & 0.04 & & 0.04 \\
\hline 479 & 0.28 & 0.13 & \\
\hline 491 & 0.04 & 0.05 & \\
\hline
\end{tabular}

B-3 


\begin{tabular}{|c|c|c|c|}
\hline $\begin{array}{c}1995 \\
\text { Deer } \\
\text { No. }\end{array}$ & $\begin{array}{c}\text { Field } \\
\text { Cs-137 } \\
\text { pCi/g }\end{array}$ & $\begin{array}{c}\text { Muscle } \\
\text { Cs-137 } \\
\text { pCi/g }\end{array}$ & $\begin{array}{c}\text { Liver } \\
\text { Cs-137 } \\
\text { pCi/g }\end{array}$ \\
\hline 4 & 0.09 & & 0.00 \\
\hline $5-c$ & 0.4 & & \\
\hline 58 & 0.12 & & 0.02 \\
\hline 78-c & 0.02 & & \\
\hline 88 & 0.07 & & 0.07 \\
\hline 105 & -0.05 & & 0.23 \\
\hline 121 & 0.05 & & 0.15 \\
\hline 134 & 0.1 & 0.11 & \\
\hline 154 & 0.01 & & 0.95 \\
\hline 160 & 0.3 & & 0.08 \\
\hline 168 & 0.52 & & 0.05 \\
\hline 174 & 0.94 & 0.02 & \\
\hline 180 & 0.09 & & 0.07 \\
\hline $203-c$ & 0.14 & & 0.05 \\
\hline $221-c$ & 0.96 & & \\
\hline $238-\mathrm{c}$ & 0.36 & & \\
\hline 241 & 0.51 & & 0.15 \\
\hline 258 & 0.36 & & 0.17 \\
\hline 278 & 0.62 & & 0.19 \\
\hline 292 & 0.41 & & 0.23 \\
\hline 328 & -0.09 & 0.05 & \\
\hline 330 & -0.14 & & 0.04 \\
\hline 378 & 0.05 & & 0.07 \\
\hline 379 & 0.51 & & 0.05 \\
\hline 381 & 0.15 & & 0.09 \\
\hline 429 & 0.1 & & 0.02 \\
\hline 433-c & 0.12 & & \\
\hline 445 & -0.17 & & 0.10 \\
\hline $447-c$ & 0 & & \\
\hline 448 & 0.41 & & 0.76 \\
\hline 461 & -0.05 & & 0.13 \\
\hline 465 & -0.05 & & 0.07 \\
\hline \multicolumn{4}{|c|}{ Chuck Swan -- Background Deer (Collected in 1994) } \\
\hline Bkgl & & 0.30 & $<0.216$ \\
\hline Bkg2 & & 0.27 & $<0.189$ \\
\hline Bkg3 & & $<0.27$ & 0.04 \\
\hline Bkg4 & & 0.32 & $<0.135$ \\
\hline
\end{tabular}

B-4 


\begin{tabular}{|cccc|}
\hline $\begin{array}{c}1996 \\
\text { Deer } \\
\text { No. }\end{array}$ & $\begin{array}{c}\text { Field } \\
\text { Cs-137 } \\
\text { pCig }\end{array}$ & $\begin{array}{c}\text { Muscle } \\
\text { Cs-137 } \\
\text { pCi/g }\end{array}$ & $\begin{array}{c}\text { Liver } \\
\text { Cs-137 } \\
\text { pCig/ }\end{array}$ \\
\hline \hline 9 & 0.36 & & 0.043 \\
33 & 0.28 & & 0.14 \\
49 & 0.39 & & 0.06 \\
72 & 0.23 & & 0.37 \\
81 & 0.42 & & 0.15 \\
108 & 0.2 & & 0.13 \\
123 & 0.36 & & 0.07 \\
144 & -0.09 & & 0.1 \\
168 & -0.09 & 0.044 & \\
172 & 0.12 & & 0.15 \\
193 & -0.09 & & -0.06 \\
215 & 0.05 & 0.077 & \\
226 & 0.26 & & 0.05 \\
247 & -0.09 & & 0.14 \\
277 & 0.4 & & 0.095 \\
286 & -0.11 & & 0.059 \\
302 & 0.2 & & 0.06 \\
328 & 0.57 & & 0.01 \\
350 & 0.24 & & 0.03 \\
371 & 0.38 & & -0.02 \\
387 & 0.17 & & 0.024 \\
405 & 0.18 & 0.07 & 0.32 \\
411 & 0.53 & & 0.04 \\
426 & 0.32 & & -0.11 \\
464 & 0.1 & & 0.027 \\
Jones Island & & & \\
& & & \\
& & & \\
\hline
\end{tabular}

\begin{tabular}{|cccc|}
\hline $\begin{array}{c}1997 \\
\text { Deer } \\
\text { No. }\end{array}$ & $\begin{array}{c}\text { Field } \\
\text { Cs-137 } \\
\text { pCi/g }\end{array}$ & $\begin{array}{c}\text { Muscle } \\
\text { Cs-137 } \\
\text { pCi/g }\end{array}$ & $\begin{array}{c}\text { Liver } \\
\text { Cs-137 } \\
\text { pCi/g }\end{array}$ \\
\hline \hline 36 & 0.03 & & 0.26 \\
48 & -0.18 & & 0.027 \\
59 & 0.22 & & 0.071 \\
206 & -0.17 & & 0.013 \\
251 & -0.12 & & 0.09 \\
265 & 0.15 & & 0.079 \\
326 & 0.05 & & 0.052 \\
408 & 0.43 & & $1.00 \mathrm{E}-03$ \\
\hline
\end{tabular}

\section{B-5}


Appendix C: Beta Count Rate and ${ }^{90} \mathrm{Sr}$ Concentrations in Bone Tables

\begin{tabular}{|c|c|c|c|}
\hline 1990 & $\begin{array}{c}\text { Deer } \\
\text { Number }\end{array}$ & $\begin{array}{c}\text { Beta } \\
\text { Activity } \\
\text { (cpm) }\end{array}$ & $\begin{array}{c}\text { Sr-90 } \\
\text { Bone Conc } \\
\text { (pCi/g) }\end{array}$ \\
\hline & 10 & 0.02 & 6.20 \\
\hline & 15 & 0.01 & 5.40 \\
\hline & 17 & 0.01 & 2.20 \\
\hline & 20 & 4.02 & 2.30 \\
\hline & 30 & 3.02 & 4.30 \\
\hline & 31 & 12.01 & 5.10 \\
\hline & 32 & 9.02 & 3.80 \\
\hline & 40 & 11.02 & 1.80 \\
\hline & 50 & 1.02 & 4.30 \\
\hline & 59 & 7.01 & 6.80 \\
\hline & 60 & 3.02 & 2.60 \\
\hline & 65 & 4.01 & 3.80 \\
\hline & 70 & 0.02 & 3.80 \\
\hline & 80 & 2.02 & 5.10 \\
\hline & 90 & 0.02 & 3.50 \\
\hline & 95 & 8.01 & 8.10 \\
\hline & 100 & 0.02 & 3.20 \\
\hline & 101 & 5.01 & 3.50 \\
\hline & 103 & 11.01 & 5.40 \\
\hline & 109 & 6.01 & 6.50 \\
\hline & 110 & 2.02 & 5.60 \\
\hline & 120 & 6.02 & 3.00 \\
\hline & 123 & 7.01 & 18.00 \\
\hline & 130 & 0.02 & 11.00 \\
\hline & 132 & 6.02 & 2.50 \\
\hline & 134 & 7.02 & 9.20 \\
\hline & 140 & 0.02 & 3.00 \\
\hline & 141 & 8.01 & 7.30 \\
\hline & 143 & 3.01 & 5.90 \\
\hline & 144 & 8.02 & 5.10 \\
\hline & $163-c$ & 92 & 270.00 \\
\hline & $189-c$ & 234 & 810.00 \\
\hline & 277-c & 74 & 130.00 \\
\hline
\end{tabular}

C-1 


\begin{tabular}{|cccc|}
\hline 1991 & $\begin{array}{c}\text { Deer } \\
\text { Number }\end{array}$ & $\begin{array}{c}\text { Beta } \\
\text { Activity } \\
\text { (cpm) }\end{array}$ & $\begin{array}{c}\text { Sr-90 } \\
\text { Bone Conc } \\
\text { (pCi/g) }\end{array}$ \\
\hline 1 & 11 & 4.90 \\
7 & 12 & 6.50 \\
$8-\mathrm{c}$ & 107.02 & 200.00 \\
10 & 4.02 & 5.40 \\
13 & 13.02 & 2.50 \\
18 & 16.02 & 4.10 \\
35 & 11.01 & 3.00 \\
53 & 13.05 & 4.10 \\
59 & 17.01 & 4.90 \\
$63-\mathrm{c}$ & 73.01 & 78.00 \\
64 & 14.02 & 8.90 \\
88 & 12.02 & 4.10 \\
103 & 14.01 & 6.20 \\
134 & 15.02 & 5.40 \\
136 & 15.02 & 6.80 \\
140 & 14.02 & 5.90 \\
\hline
\end{tabular}

\begin{tabular}{|cccc|}
\hline 1992 & $\begin{array}{c}\text { Deer } \\
\text { Number }\end{array}$ & $\begin{array}{c}\text { Beta } \\
\text { Activity } \\
\text { (cpm) }\end{array}$ & $\begin{array}{c}\text { Sr-90 } \\
\text { Bone Conc } \\
\text { (pCi/g) }\end{array}$ \\
\hline $134-\mathrm{c}$ & 5 & 7.60 \\
136 & 0 & 6.80 \\
140 & 7 & 5.90 \\
158 & 0 & 3.20 \\
166 & 11 & 6.70 \\
177 & 17 & 3.60 \\
$198-\mathrm{c}$ & 302 & 290.00 \\
229 & 8 & 4.80 \\
$230-\mathrm{c}$ & 22 & 11.00 \\
$245-\mathrm{c}$ & 146 & 97.00 \\
$246-\mathrm{c}$ & 426 & 300.00 \\
270 & 9 & 2.40 \\
$277-\mathrm{c}$ & 99 & 110.00 \\
$281-\mathrm{c}$ & 68 & 60.00 \\
288 & 16 & 6.10 \\
294 & 12 & 8.20 \\
297 & 15 & 2.30 \\
311 & 11 & 4.20 \\
361 & 0 & 3.50 \\
362 & 0 & 2.70 \\
368 & 0 & 3.00 \\
370 & 11 & 4.30 \\
\hline
\end{tabular}

C-2 


\begin{tabular}{|c|c|c|c|}
\hline 1993 & $\begin{array}{c}\text { Deer } \\
\text { Number }\end{array}$ & $\begin{array}{c}\text { Beta } \\
\text { Activity } \\
\text { (cpm) }\end{array}$ & $\begin{array}{c}\text { Sr-90 } \\
\text { Bone Conc } \\
\text { (pCi/g) }\end{array}$ \\
\hline & 2 & 12 & 15.12 \\
\hline & 6 & 9 & 2.16 \\
\hline & 13 & 8.5 & 2.43 \\
\hline & 21-c & 18 & 32.40 \\
\hline & - 33 & 10.5 & 7.29 \\
\hline \multicolumn{4}{|c|}{73} \\
\hline & $75-c$ & 24 & 32.40 \\
\hline & 81 & 8 & 0.81 \\
\hline & 99 & 9 & -0.81 \\
\hline & 102 & 6.5 & 9.72 \\
\hline & 122 & 6.5 & 2.43 \\
\hline & $123-\mathrm{c}$ & 82 & 62.10 \\
\hline & 163 & 7.5 & -2.43 \\
\hline & 200 & 0 & 0.46 \\
\hline & 215 & 7 & 7.29 \\
\hline & 227 & 5.5 & 1.89 \\
\hline & $261-c$ & 49 & 26.19 \\
\hline & 268 & 0 & -1.08 \\
\hline & 273 & 0 & 9.45 \\
\hline & $278-c$ & 37 & 37.80 \\
\hline & 300 & 7.5 & 0.00 \\
\hline & 315 & 0.5 & 1.08 \\
\hline & $317-c$ & 155 & 67.50 \\
\hline & 333 & 0 & 0.00 \\
\hline & $340-\mathrm{c}$ & 30.5 & 29.70 \\
\hline & 344 & 7.5 & 16.20 \\
\hline & 385 & 1 & 2.70 \\
\hline
\end{tabular}




\begin{tabular}{|c|c|c|c|}
\hline 1994 & $\begin{array}{c}\text { Deer } \\
\text { Number }\end{array}$ & $\begin{array}{c}\text { Beta } \\
\text { Activity } \\
\text { (cpm) }\end{array}$ & $\begin{array}{c}\text { Sr-90 } \\
\text { Bone Conc } \\
\text { (pCi/g) }\end{array}$ \\
\hline & 7 & 4.5 & 3.51 \\
\hline & 8 & 9.5 & 2.67 \\
\hline & 9 & 8 & 2.62 \\
\hline & 35 & 8.5 & 4.05 \\
\hline & 77 & 0 & 2.21 \\
\hline & 92 & 0 & 2.97 \\
\hline & .100 & 5.5 & 2.97 \\
\hline & 102 & 7.5 & 35.10 \\
\hline & 110 & 0 & 2.21 \\
\hline & 117 & 0 & 1.03 \\
\hline & 120 & 4 & 0.86 \\
\hline & 139 & 10 & -0.51 \\
\hline & 143 & 9 & 0.62 \\
\hline & 145 & 9.5 & 3.24 \\
\hline & 147 & 2 & 3.24 \\
\hline & 157 & 1.5 & 2.54 \\
\hline & 174 & 2.5 & 2.97 \\
\hline & 175 & 3.5 & 3.78 \\
\hline & 181 & 0 & 3.24 \\
\hline & 220 & 0 & 2.70 \\
\hline & $231-c$ & 10 & 32.40 \\
\hline & 247 & 7 & 5.13 \\
\hline & $248-c$ & 160 & 297.00 \\
\hline & 253 & 1 & 4.86 \\
\hline & $283-c$ & 351.5 & 405.00 \\
\hline & $289-c$ & 33.5 & 67.50 \\
\hline & $291-c$ & 54 & 143.10 \\
\hline & 308 & 6 & 5.13 \\
\hline & 319 & 4.5 & 4.86 \\
\hline & 341 & 0 & 4.59 \\
\hline & 347 & 0 & 2.65 \\
\hline & 388 & 6.5 & 2.05 \\
\hline & 405 & 0.5 & 1.38 \\
\hline & 406 & 5.5 & 4.05 \\
\hline & $409-c$ & 413 & 594.00 \\
\hline & 412 & 8 & 2.03 \\
\hline & 418 & 7.5 & 4.59 \\
\hline & $429-c$ & 30.5 & 45.90 \\
\hline & 435 & 0 & 1.70 \\
\hline & $441-c$ & 27 & 62.10 \\
\hline & 451 & 3 & 5.67 \\
\hline & 479 & 0 & 4.32 \\
\hline & 491 & 2.5 & 10.26 \\
\hline
\end{tabular}

C-4 


\begin{tabular}{|c|c|c|c|}
\hline 1995 & $\begin{array}{c}\text { Deer } \\
\text { Number }\end{array}$ & $\begin{array}{c}\text { Beta } \\
\text { Activity } \\
\text { (cpm) }\end{array}$ & $\begin{array}{c}\text { Sr-90 } \\
\text { Bone Conc } \\
\text { (pCi/g) }\end{array}$ \\
\hline & 4 & 5.5 & 13 \\
\hline & 5-c & 222.5 & 486 \\
\hline & 58 & 4.5 & 10 \\
\hline & 78-c & 246 & 432 \\
\hline & 88 & 4 & 5.7 \\
\hline & 105 & 5 & 32 \\
\hline & $121^{\circ}$ & 6.5 & 8.4 \\
\hline & 134 & 6 & 8.9 \\
\hline & 154 & 9.5 & 8.4 \\
\hline & 160 & 0.5 & 12 \\
\hline & $164-c$ & 79 & 237.6 \\
\hline & 168 & 4.5 & 9.7 \\
\hline & 174 & 11.5 & 30 \\
\hline & 180 & 7.5 & 12 \\
\hline & $203-c$ & 27.5 & 40.5 \\
\hline & $221-c$ & 187.5 & 270 \\
\hline & $238-c$ & 84 & 124.2 \\
\hline & 241 & 9.5 & 16 \\
\hline & 258 & 4 & 10 \\
\hline & 278 & 4.5 & 11 \\
\hline & 292 & 5 & 16 \\
\hline & 328 & 0 & 11 \\
\hline & 330 & 0 & 12 \\
\hline & 378 & 0 & 15 \\
\hline & 379 & 0 & 15 \\
\hline & 381 & 3.5 & 13 \\
\hline & 429 & 0 & 8.4 \\
\hline & $433-c$ & 295 & 567 \\
\hline & 445 & 1 & 18 \\
\hline & 447-c & 22.5 & 18.36 \\
\hline & 448 & 0 & 14 \\
\hline & 461 & 4.5 & 10 \\
\hline & 465 & 2 & 19 \\
\hline
\end{tabular}

C-5 


\begin{tabular}{|c|c|c|c|}
\hline 1996 & $\begin{array}{c}\text { Deer } \\
\text { Number }\end{array}$ & $\begin{array}{c}\text { Beta } \\
\text { Activity } \\
\text { (cpm) }\end{array}$ & $\begin{array}{c}\text { Sr-90 } \\
\text { Bone Conc } \\
\text { (pCi/g) }\end{array}$ \\
\hline & 9 & 0 & 0.37 \\
\hline & 49 & 4 & -0.07 \\
\hline & 72 & 2 & 0.28 \\
\hline & 81 & 8.5 & 1.2 \\
\hline & 108 & 3 & 1.1 \\
\hline & 123 & 4.5 & 1 \\
\hline & 144 & 9 & 0.55 \\
\hline & $168-c$ & 35.5 & 7.3 \\
\hline & 172 & 5 & 0.51 \\
\hline & 193 & 4.5 & 0.29 \\
\hline & 215 & 9.5 & 0.32 \\
\hline & 226 & 5.5 & 0.04 \\
\hline & 247 & 8 & 0.44 \\
\hline & 277 & 9 & 4.1 \\
\hline & 286 & 3 & 0.7 \\
\hline & 302 & 5 & 0.65 \\
\hline & 328 & 0 & 0.42 \\
\hline & 350 & 7 & 0.23 \\
\hline & 371 & 8 & 0.86 \\
\hline & 387 & 0 & 0.4 \\
\hline & $405-c$ & 29 & 5.4 \\
\hline & 411 & 10 & 0.47 \\
\hline & 426 & 7.5 & 0.47 \\
\hline & 464 & 5 & 0.76 \\
\hline
\end{tabular}


Appendix D : Sr-90 Concentrations in Tissue and Bone

\begin{tabular}{|c|c|c|c|c|c|c|}
\hline Year & $\begin{array}{c}\text { Deer } \\
\text { Number }\end{array}$ & $\begin{array}{c}\text { Liver Sr-90 } \\
\text { Concentration } \\
\text { pCi/g }\end{array}$ & $\begin{array}{c}\text { Muscle } \mathrm{Sr}-90 \\
\text { Concentration } \\
\mathrm{pCi} / \mathrm{g}\end{array}$ & $\begin{array}{c}\text { Bone Sr-90 } \\
\text { Concentration } \\
\text { pCi/g }\end{array}$ & $\begin{array}{c}\text { Liver:Bone } \\
\text { Ratio }\end{array}$ & $\begin{array}{c}\text { Muscle: Bone } \\
\text { Ratio }\end{array}$ \\
\hline \multirow[t]{3}{*}{1990} & 163 & -0.05 & -0.01 & 270.27 & $-1.70 \mathrm{E}-04$ & $-1.85 E-05$ \\
\hline & 189 & 0.02 & -0.02 & 810.81 & $2.67 \mathrm{E}-05$ & $-3.00 \mathrm{E}-05$ \\
\hline & 277 & 0.05 & 0.00 & 132.43 & $3.67 \mathrm{E}-04$ & 2.27E-05 \\
\hline \multirow[t]{16}{*}{1991} & 1 & 0.23 & & 4.90 & $4.63 \mathrm{E}-02$ & \\
\hline & 7 & 0.11 & & 6.50 & $1.62 \mathrm{E}-02$ & \\
\hline & 8 & 0.07 & -0.15 & 200.00 & $3.50 \mathrm{E}-04$ & $-7.70 \mathrm{E}-04$ \\
\hline & 10 & & 0.09 & 5.40 & & $1.67 \mathrm{E}-02$ \\
\hline & 13 & -0.05 & & 2.50 & $-2.00 \mathrm{E}-02$ & \\
\hline & 18 & 0.17 & & 4.10 & $4.15 \mathrm{E}-02$ & \\
\hline & 35 & 0.04 & & 3.00 & $1.33 \mathrm{E}-02$ & \\
\hline & 53 & & 0.24 & 4.10 & & $5.80 \mathrm{E}-02$ \\
\hline & 59 & & 0.09 & 4.90 & & $1.84 E-02$ \\
\hline & 63 & 0.41 & 0.03 & 78.00 & $5.20 \mathrm{E}-03$ & $3.85 \mathrm{E}-04$ \\
\hline & 64 & -0.14 & & 8.90 & $-1.52 \mathrm{E}-02$ & \\
\hline & 88 & 0.05 & & 4.10 & $1.22 \mathrm{E}-02$ & \\
\hline & 103 & 0.16 & & 6.20 & 2.62E-02 & \\
\hline & 134 & 0.25 & & 5.40 & $4.65 \mathrm{E}-02$ & \\
\hline & 136 & 0.03 & & 6.80 & $4.41 \mathrm{E}-03$ & \\
\hline & 140 & & 0.02 & 5.90 & & $3.39 \mathrm{E}-03$ \\
\hline \multirow[t]{15}{*}{1992} & 1 & 0.05 & & * & & \\
\hline & 7 & 0.09 & & * & & \\
\hline & 8 & 0.00 & & * & & \\
\hline & 18 & & -0.01 & * & & \\
\hline & 23 & & 0.08 & * & & \\
\hline & 49 & & 0.06 & * & & \\
\hline & 58 & 0.03 & & * & & \\
\hline & 64 & & -0.02 & $*$ & & $\cdot$ \\
\hline & 68 & 0.11 & & * & & \\
\hline & 104 & 0.01 & & * & & \\
\hline & 110 & 0.01 & & * & & \\
\hline & 111 & 0.05 & & * & & \\
\hline & 113 & 0.02 & & * & & \\
\hline & 121 & & 0.05 & * & & \\
\hline & 127 & & 0.04 & * & & \\
\hline \multirow[t]{23}{*}{1996} & 9 & 0.05 & & 0.37 & $1.35 \mathrm{E}-01$ & \\
\hline & 33 & 0.20 & & 0.03 & $6.67 \mathrm{E}+00$ & \\
\hline & 49 & 0.05 & & -0.07 & $-7.14 \mathrm{E}-01$ & \\
\hline & 72 & 0.04 & & 0.28 & $1.43 \mathrm{E}-01$ & \\
\hline & 81 & -0.02 & & 1.20 & $-1.67 \mathrm{E}-02$ & \\
\hline & 108 & -0.06 & & 1.10 & $-5.64 \mathrm{E}-02$ & \\
\hline & 123 & 0.00 & & 1.00 & $0.00 E+00$ & \\
\hline & 144 & -0.04 & & 0.55 & $-7.27 E-02$ & \\
\hline & 172 & 0.04 & & 0.51 & $8.63 \mathrm{E}-02$ & \\
\hline & 193 & 0.08 & & 0.29 & $2.90 \mathrm{E}-01$ & \\
\hline & 226 & 0.06 & - & 0.04 & $1.38 \mathrm{E} \div 00$ & \\
\hline & 247 & -0.04 & & 0.44 & $-8.18 E-02$ & \\
\hline & 277 & 0.05 & $\cdot$ & 4.10 & $1.17 \mathrm{E}-02$ & \\
\hline & 286 & -0.08 & & 0.70 & $-1.16 \mathrm{E}-01$ & \\
\hline & 302 & 0.05 & & 0.65 & $7.38 \mathrm{E}-02$ & \\
\hline & 328 & -0.01 & & 0.42 & $-2.38 \mathrm{E}-02$ & \\
\hline & 350 & -0.08 & & 0.23 & $-3.48 \mathrm{E}-01$ & \\
\hline & 371 & -0.02 & & 0.86 & $-2.33 \mathrm{E}-02$ & \\
\hline & 387 & -0.08 & & 0.40 & $-2.00 \mathrm{E}-01$ & \\
\hline & 405 & 0.00 & & 5.40 & $-3.33 E-04$ & \\
\hline & 411 & -0.15 & & 0.47 & $-3.19 \mathrm{E}-01$ & \\
\hline & 426 & -0.03 & & 0.47 & $-6.38 \mathrm{E}-02$ & \\
\hline & 464 & -0.12 & & 0.76 & $-1.58 \mathrm{E}-01$ & \\
\hline
\end{tabular}

* no coinciding $\mathrm{Sr}-90$ in bone data 


\section{Distribution List}

Internal Distribution

Larry Bible, CASD, Bldg. 2026, MS 6043 (2)

Rick Dailey, OEP, Bldg. 4500S, MS 6102

Karen Downer, OEP, Bldg. 4500N, MS 6198

Joan Hughes, OEP, Bldg. 4500S, MS 6102

John Keller, CASD, Bldg. 2026, MS 6043

Frank Kornegay, SNS, MS 8218

Frank O'Donnell, OEP, Bldg. 4500S, MS 6102

Pat Parr, ESD, Bldg. 1505, MS 6038

Wayne Parsons, OEP, Bldg. 4500S, MS 6102

David Skipper, OEP, BIdg. 4500N, MS 6198

Warren Web, ESD, Bldg. 1505, MS 6036

Central Research Library

Laboratory Records - RC

Laboratory Records - OSTI (2)

External Distribution

Jim Donnelly, ORO, FEDBLDG, MS SE32

Jim Evans, TDEC, Bldg. 0907, MS 6490

Norm Teasley, Jr., 1008 Chateaugay Rd, Knoxville TN 37923 